\title{
Calcium Phosphate Nanoparticles-Based Systems for RNAi Delivery: Applications in Bone Tissue Regeneration
}

\author{
Tanya J. Levingstone $\mathrm{1}^{1,2,3,4,+\oplus \text {, Simona Herbaj }}{ }^{1,2,+}{ }^{,}$John Redmond ${ }^{1,2}$, Helen O. McCarthy ${ }^{5}$ and \\ Nicholas J. Dunne $1,2,3,4,5,6,7, *$ \\ 1 School of Mechanical and Manufacturing Engineering, Dublin City University, 9 Dublin, Ireland; \\ tanya.levingstone@dcu.ie (T.J.L.); simona.herbaj2@mail.dcu.ie (S.H.); john.redmond23@mail.dcu.ie (J.R.) \\ 2 Centre for Medical Engineering Research, School of Mechanical and Manufacturing Engineering, Dublin \\ City University, 9 Dublin, Ireland \\ 3 Advanced Processing Technology Research Centre, Dublin City University, 9 Dublin, Ireland \\ 4 Trinity Centre for Biomedical Engineering, Trinity Biomedical Sciences Institute, Trinity College Dublin, \\ 2 Dublin, Ireland \\ 5 School of Pharmacy, Queen's University Belfast, Belfast BT9 7BL, UK; h.mccarthy@qub.ac.uk \\ 6 Department of Mechanical and Manufacturing Engineering, School of Engineering, Trinity College Dublin, \\ 2 Dublin, Ireland \\ 7 Advanced Materials and Bioengineering Research Centre (AMBER), Royal College of Surgeons in Ireland \\ and Trinity College Dublin, 2 Dublin, Ireland \\ * Correspondence: nicholas.dunne@dcu.ie; Tel.: +353-(0)1-700-5712; Fax: +353-(0)1-700-7148 \\ + These authors contributed equally to this work.
}

Received: 4 October 2019; Accepted: 21 December 2019; Published: 14 January 2020

check for updates

\begin{abstract}
Bone-related injury and disease constitute a significant global burden both socially and economically. Current treatments have many limitations and thus the development of new approaches for bone-related conditions is imperative. Gene therapy is an emerging approach for effective bone repair and regeneration, with notable interest in the use of RNA interference (RNAi) systems to regulate gene expression in the bone microenvironment. Calcium phosphate nanoparticles represent promising materials for use as non-viral vectors for gene therapy in bone tissue engineering applications due to their many favorable properties, including biocompatibility, osteoinductivity, osteoconductivity, and strong affinity for binding to nucleic acids. However, low transfection rates present a significant barrier to their clinical use. This article reviews the benefits of calcium phosphate nanoparticles for RNAi delivery and highlights the role of surface functionalization in increasing calcium phosphate nanoparticles stability, improving cellular uptake and increasing transfection efficiency. Currently, the underlying mechanistic principles relating to these systems and their interplay during in vivo bone formation is not wholly understood. Furthermore, the optimal microRNA targets for particular bone tissue regeneration applications are still unclear. Therefore, further research is required in order to achieve the optimal calcium phosphate nanoparticles-based systems for RNAi delivery for bone tissue regeneration.
\end{abstract}

Keywords: bone tissue engineering; calcium phosphates; gene therapy; nanoparticles; non-viral vectors; RNA interference; surface functionalization

\section{Introduction}

Despite bone's intrinsic ability to repair itself without scarring, $5-10 \%$ of all bone fractures result in delayed or non-union fractures [1], causing chronic pain for patients. This impacts significantly on 
patient quality of life and places a significant burden on the health system with the cost of treating non-union fractures in the USA expected to rise from $\$ 19$ billion (2005) per annum to $\$ 25$ billion by 2025 [2]. Autologous bone grafts, the "gold standard" currently employed to treat delayed or non-union fractures, exhibit a high incidence of failure and numerous limitations, including donor site morbidity, lack of tissue availability, and invasive surgery [3]. Similar drawbacks, such as unfavorable immune responses, rejection rates and lack of graft availability, are found in the use of allografts and xenografts, whereas synthetic bone graft substitutes often lack biocompatibility and osteogenic potential [4]. The combination of protein therapy with synthetic bone grafts has demonstrated promising early results. However, the low retention rate and high concentration of protein required to obtain a biological effect is a cause for concern [5]. Consequently, there is an increasing need for and interest in the development of new, effective therapies for bone regeneration.

Gene therapy is considered as the latest approach for the repair of challenging bone defects-delivering exogenous deoxyribonucleic acid (DNA) or ribonucleic acid (RNA) to obtain controlled and sustained protein expression at the fracture site [6]. In particular over the last two decades, the important role played by RNA interference (RNAi) mediated gene repression/silencing in bone metabolism through the regulation of the proliferation, differentiation and function of bone cells has been recognized and RNA-based therapies have shown promise for bone regeneration [7]. In contrast to DNA-based technologies, RNA-based approaches offer the advantage of utilizing a cell's own internal machinery to alter the gene expression. Furthermore, as RNA-based therapeutics do not require nuclear entry, these molecules completely avoid the risk of insertional mutagenesis and therefore present a safer and more viable alternative [8]. However, the delivery of RNA is often hampered by its susceptibility to degradative enzymes, which present a significant limitation to its use. $[8,9]$. Furthermore, its poor capacity to penetrate the host cell membrane and selectively distribute to the desired tissues or cells within the body presents a significant barrier to clinical translation [7]. Thus, the establishment of a carrier that would increase protection, intracellular release and expression of genetic material is imperative. Calcium phosphate nanoparticles hold particular potential in this regard for bone-related conditions as they have a strong affinity for binding to nucleic acids $[10,11]$. They are also well-accepted by the body and have a significant surface-to-volume ratio that allows for a higher driving force for diffusion, increased particle solubility and adhesion to specific proteins [12]. Furthermore, calcium phosphate-based systems are osteoconductive, osteoinductive, and the majority are considered bioresorbable [13]. This review provides a synopsis of the current state-of-the-art relating to the design of calcium phosphate nanoparticles as non-viral vectors and their application in RNA-based therapy for bone tissue regeneration. The potential for surface functionalization methods to improve the stability, transfection and safety of calcium phosphate will also be discussed.

\section{RNA Interference for Bone Repair}

\subsection{Biogenesis of microRNA and siRNA}

RNAi offers significant prospects for the development of next generation bone tissue engineering therapeutics. Two types of RNA are fundamental to RNAi, microRNA (miRNA) and silencing RNA (siRNA). miRNAs are naturally occurring non-coding single strand hairpin of RNA about 20-25 nucleotides long. Primary miRNAs (pri-miRNA) are produced by RNA polymerase II and appear as a longer sequence of RNA which includes the miRNA hairpin shape. This is recognized by the endonuclease Drosha that proceeds to the cleavage of the hairpin from the pri-miRNA at about one helical turn from the base of the hairpin [14]. Subsequently, the hairpin exits the nucleus thanks to the exportin-5 complex, where it meets another endonuclease, Dicer, which cleaves the top of the hairpin, separating the two strands [14]. One of those strands is degraded whereas the other one is then loaded onto an Argonaut protein, forming the RNA-induced silencing complex (RISC) [15]. Finally, once the miRNA is loaded onto the protein, it can control gene expression by directing the Argonaut protein towards the $3^{\prime}$-untraslated regions ( $3^{\prime}$-UTRs) of other messenger RNAs 
(mRNA) [16]. Therefore, miRNAs are directly involved in the regulation of the expression of different genes at post-transcriptional level [17] by binding to reception sites within the cells, and guiding cell proliferation, differentiation, and death (Figure 1). miRNAs can stimulate the expression of proteins such as bone morphogenetic proteins (BMPs) that are intrinsically related to osteogenesis differentiation. miRNAs are also directly involved in pathways leading to different bone conditions such as osteoporosis and osteoarthritis, as they can upregulate or downregulate genes related to those diseases [18].

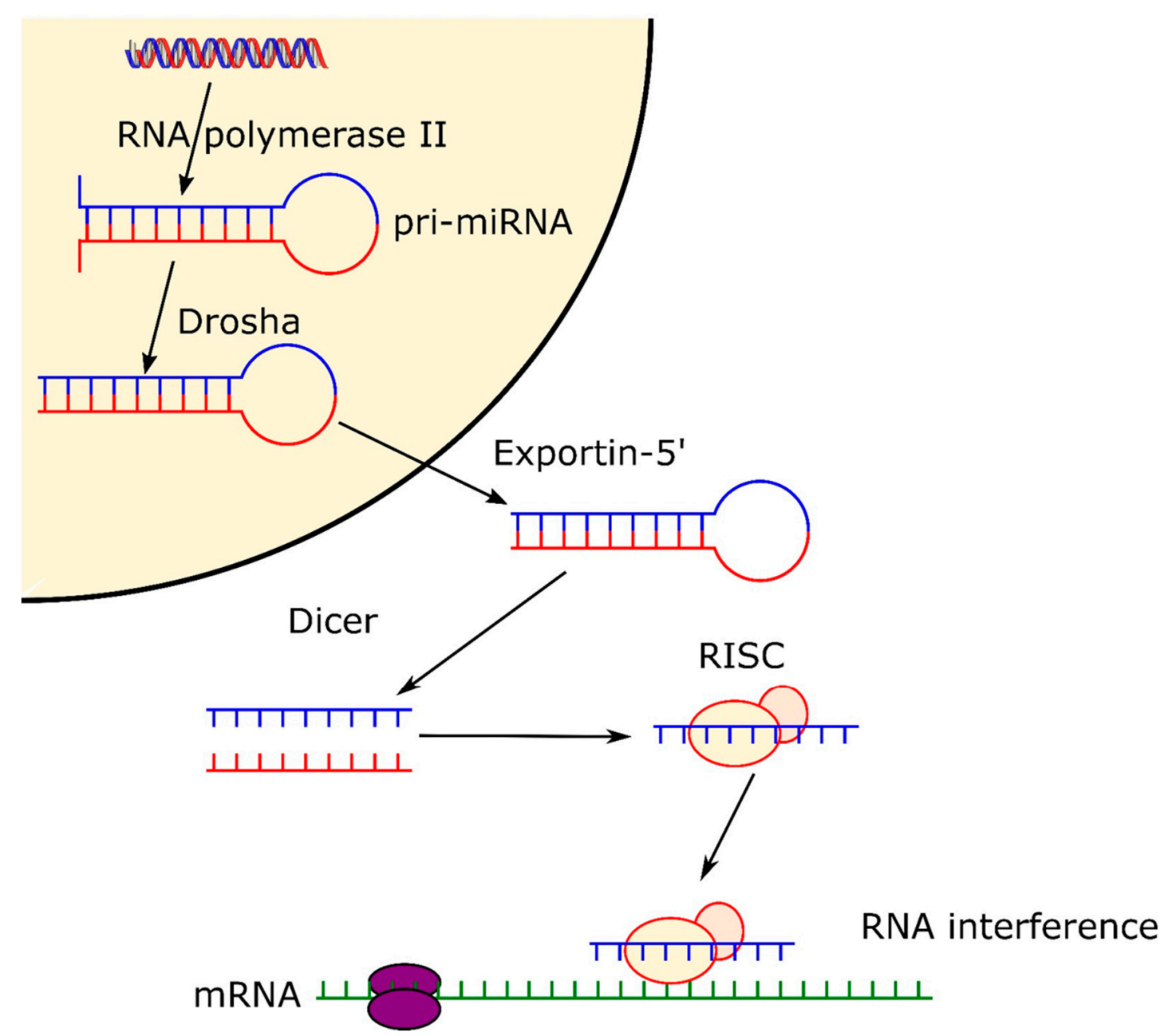

Figure 1. Pathway of microRNA, from formation in the cell nucleus thanks to RNA polymerase II, to formation of RISC complex and expression.

siRNAs are double stranded RNAs that are widely studied for specific gene silencing. The siRNAs are processed by Dicer, which cleaves them to short sequences of approximately 20 nucleotides and subsequently bind to an Argonaut protein, forming the RNA-induced silencing complex (RISC), similarly to the process followed by miRNAs [19]. Once part of the RISC, one strand of the siRNA is degraded, while the other strand, called the "guide strand" remains bound to the Argonaut protein. The siRNAs are able to perfectly match specific sites onto the mRNA, therefore silencing the expression of specific genes by endo nucleolytic cleavage of the mRNA [19], "knocking-down" the targeted gene. However, despite the high specificity of siRNA, sometimes their use can trigger an "off-target" gene [19]. This happens when the structure of the off-target gene is similar to the one of the intended target. There are a number of strategies available in order to overcome this problem: benefitting from siRNA redundancy; applying chemical modification of the siRNA; or eliminating pro-inflammatory sequences 
to avoid immune-stimulation caused by the siRNA [20]. A more in-depth analysis of the biogenesis of miRNA and siRNA along with the mechanisms of action has been reviewed elsewhere [14-16].

\subsection{Bone Interfering miRNA}

MiRNAs are shown to regulate the crosstalk between transcription factors, including osteoblast differentiation, osteoclasts and osteoblasts activation, bone remodeling, and bone diseases metabolism. Within the large spectra of miRNAs involved in the regulation of osteogenesis promotion and/or inhibition, some miRNAs have been shown to remarkably affect the bone regulating process. To date, a relatively low number of miRNAs have been investigated, leaving significant scope for further development. The effects of the principal bone interfering miRNAs which have been shown to directly interfere with the differentiation pathways of bone cells are summarized in Figure 2 and Table 1. Figure 2 highlights the miRNAs that upregulate or downregulate the differentiation of osteoblasts, osteoclasts and chondrocytes during bone repair, as well as the miRNAs that are believed to affect bone homeostasis overall, by balancing bone turnover. Of the miRNAs that influence osteoblasts differentiation, miR-26a has been most extensively investigated to date. Delivery of miR-26a has been shown to increase the expression of bone-related factors (e.g., Runt-related transcription factor 2 (RUNX2), osteocalcin (OCN) and bone morphogenetic protein-2 (BMP-2)), and vascular-related factors (e.g., VEGF and Ang1) [21] and to target the glycogen synthase kinase 3-beta (GSK-3 $\beta$ ) gene, which is responsible for augmenting bone mineralization and bone mass [22,23]. Similarly, miR-148b has been identified as a potent bone promoter [24], acting to downregulate the noggin expression, which works as an antagonist of BMPs and is produced by the NOG gene [25]. Liao et al. showed that the co-expression of miR-148b and BMP-2 can lead to an enhancement in osteogenesis compared to the separate delivery of miR-148b and BMP-2 [26].

a) BONE HOMEOSTASIS

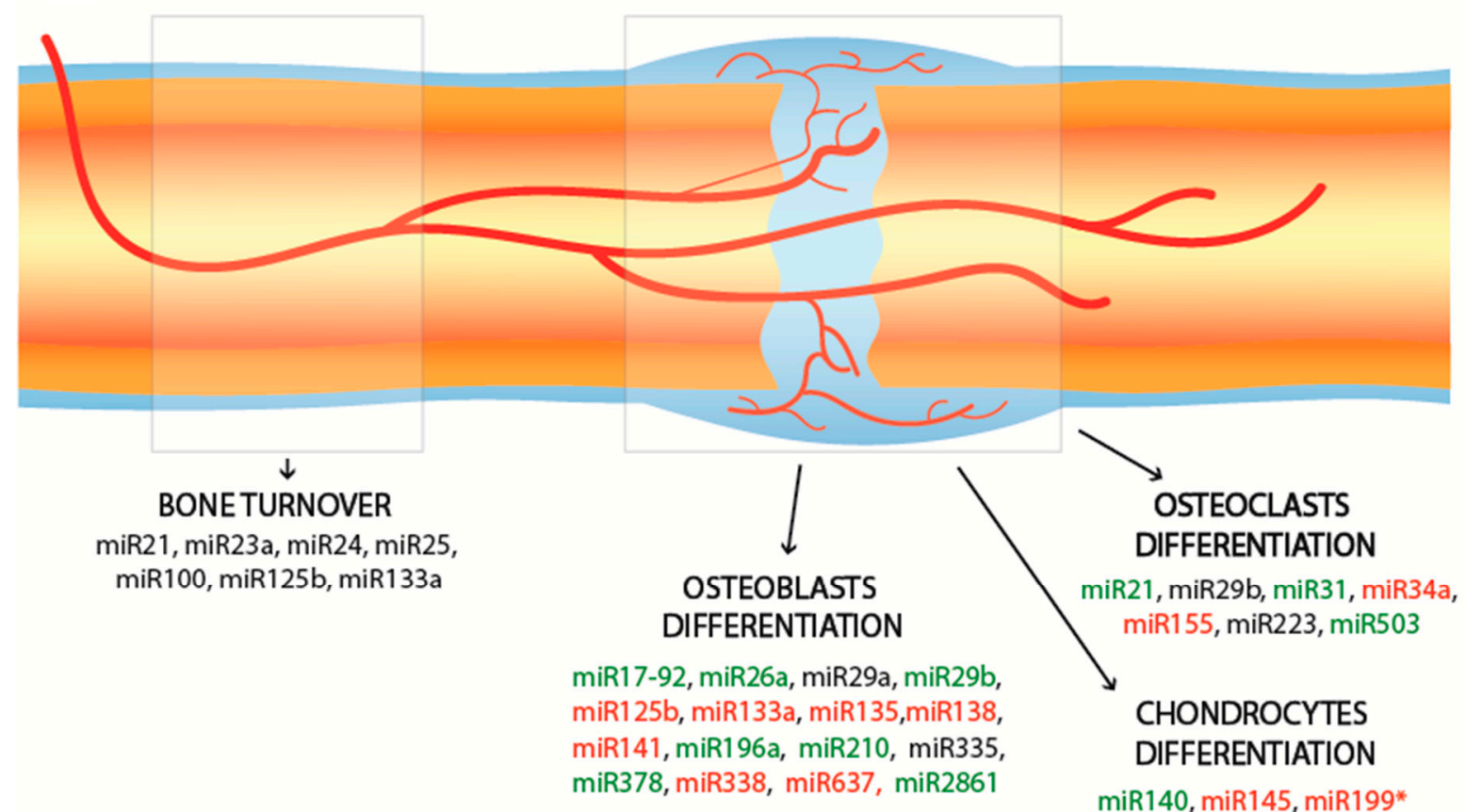

Figure 2. Schematic of miRNAs involved in bone homeostasis (a) and bone repair (b). The miRNAs involved in bone repair are distinguished in positive regulators (green), negative regulators (red), unclear (black). 
Table 1. MicroRNA for regulation of bone markers and their effect on targeted genes during bone repair.

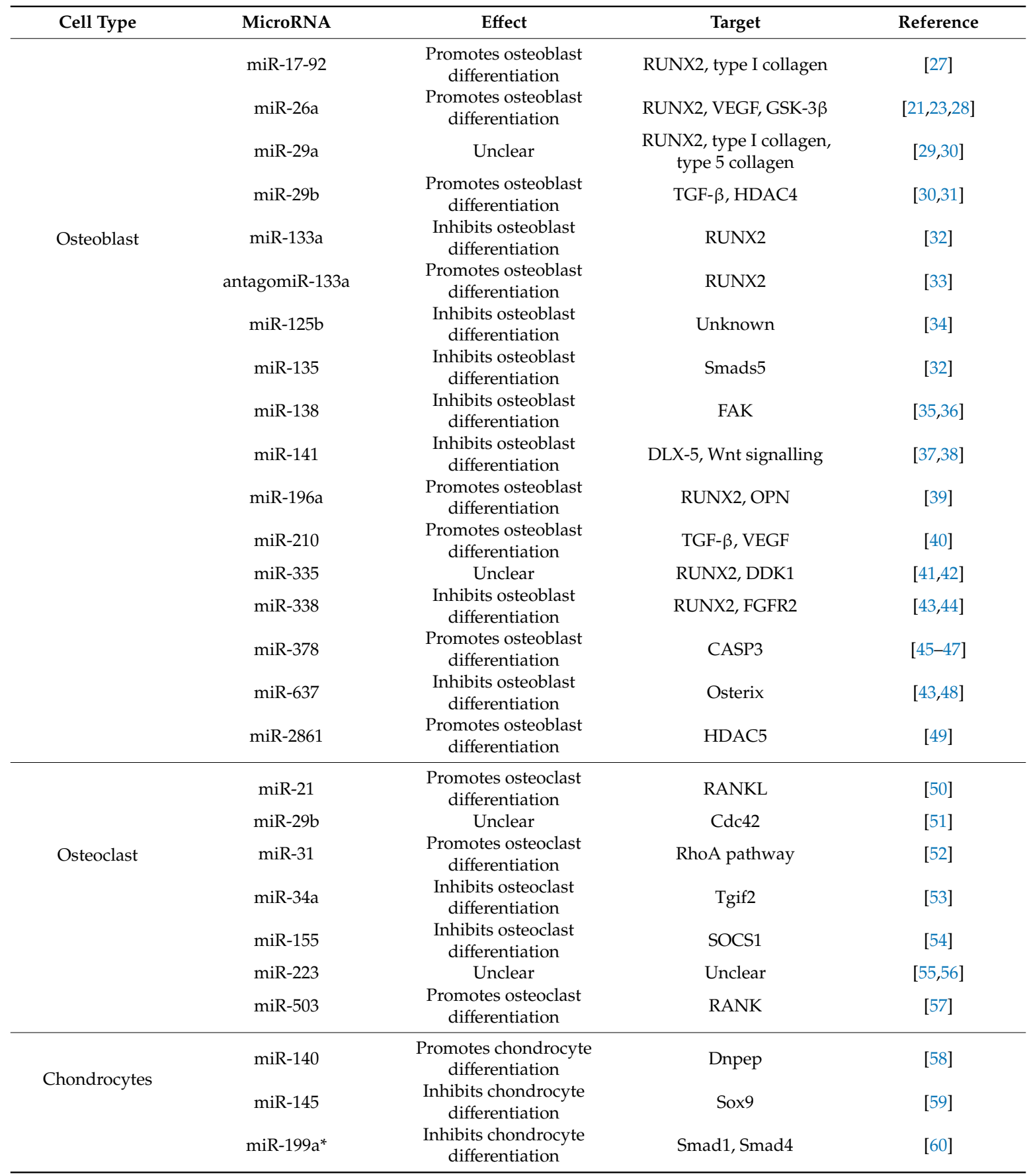

Current RNAi studies tend to focus on RUNX2 as a critical target for miRNAs since it represents a master transcription factor and is heavily involved in the regulation of multiple genes promoting osteogenesis, extracellular matrix (ECM) synthesis and bone formation [61]. Indeed, RUNX2 inhibition has severe consequences for the ability of cells to differentiate into osteoblasts [62]. RUNX2 can also promote and guide the expression of bone regulating factors such as OCN, osteopontin (OPN), and alkaline phosphatase (ALP). To enhance osteogenesis, it is possible to fabricate miRNAs to antagonize (known as antagomiRNAs) the action of miRNAs such as miR-133 to ultimately promote the expression of RUNX2 [32,33]. This approach was successfully implemented by Mencía Castaño et al. with the incorporation of antagomiR-133a into hydroxyapatite (HA) nanoparticles loaded onto a collagen scaffold [33]. These complexes inhibited miR-133 activity in human mesenchymal cells culture with 
minimal cytotoxicity. Similarly, miR-135 prevents osteogenesis by negatively interfering with Smad 5, a transducer of BMP, hence disrupting the osteogenic differentiation pathway [32]. Overexpression of miR-206 is related to osteogenic inhibition by acting on Connexin-43-a critical gap junction for osteoblast communication [63]. Finally, miR125b is found to inhibit osteoblast differentiation by acting on Osterix, a transcription factor critical for the regulation of the bone formation and bone remodeling. Indeed, Osterix-deficient mice do not survive after birth due to the incomplete formation of the skeletal system [64], whereas Osterix-deactivated mice show spinal deformities [65]. However, for some miRNAs, the impact on osteoblasts remains unclear. For example, the overexpression of miR-335 has been shown to lead to inhibition of human mesenchymal stem cells (hMSCs) proliferation and osteogenic potential [42]; whereas other studies have reported that miR-335-5p acts upon the Wnt signaling pathways that promote osteogenesis [41].

While much of the current research is focused on enhancing osteoblast differentiation, miRNAs that affect osteoclast differentiation have also been investigated. For example, miR31 has been shown to enhance osteoclastogenesis by targeting RhoA under RANKL stimulation [52]; and miR-21 can induce osteoclastogenesis by downregulating the levels of programmed cell death 4 (PDCD4) protein [50]. miR-21 has also been shown to positively correlate with risk of osteoporosis [66]. Conversely, some miRNAs have been shown to inhibit osteoclastogenesis, specifically miR-503, miR-155 and miR-34a, through targeting some osteoclasts regulator factors [53,54,57]. Similarly, as detailed in Figure 2 and Table 1, miRNAs (e.g., miR-140) that upregulate chondrocyte differentiation [58] and others (e.g., miR-199) that downregulate it [60] by interfering with the differentiation pathway have been identified. Alternatively, bone repair can be addressed by targeting miRNAs that are believed to play an essential role in regulating the healthy turnover of bone cells, also known as bone homeostasis. The discovery of most miRNAs is related to the study of osteoporosis, as this disease is intrinsically related to an imbalance between bone resorption and bone formation. Therefore, the study of these miRNA (e.g., miR-21, miR-23a, miR-24, miR-25 and miR-100) is thought to provide useful insights on the regulation of bone homeostasis [56], and could potentially be applied to achieve bone repair.

\section{Mechanisms of miRNA Delivery for Bone Repair}

Efficient, sustained and safe delivery of genetic material is essential for successful RNAi mediated gene repression, regulation and silencing. The promise of therapeutic benefits from distribution of exogenous DNA/RNA is currently limited by the lack of effective delivery systems. Current techniques for gene delivery include physical methods [67] and vector-based systems [68,69]. Physical methods for nucleic acid delivery include: naked DNA/RNA injection/microinjection [70], use of biolistic/gene gun [68], electroporation [71], and sonoporation [69]. Despite successful applications of these physical delivery techniques, significant hurdles exist impeding their use for gene therapies. In particular, genetic material delivered using these techniques rapidly comes under attack from endonucleases resulting in a poor half-life of DNA/RNA, leading to a low likelihood of the gene therapy reaching its destination-first to the cell and then the nucleus. The incorporation and/or encapsulation of genetic cargo using vectors/carriers has resulted in greater success. These vector-based systems can be sub-divided into two further classes: (1) Viral [72] and (2) non-viral [73] systems. Viral and non-viral approaches used in RNA-based therapies have reviewed extensively within the literature [7,74,75].

\subsection{Viral Vectors}

Viral vectors are considered to be highly effective methods of nucleic acid delivery as they provide high transfection rates taking advantage of the intrinsic mechanisms viruses have to infect host cells [76]. Use of viral vectors (e.g., adenoviruses, retroviruses, adeno-associated viruses and lentiviruses) for therapeutic delivery applications [76-79] has demonstrated the successful intracellular delivery of pDNA for generation of RNAi molecules including for bone-related conditions [80-82]. However, some limitations and safety concerns related to using viral vectors has resulted in a low number of clinical products being approved by the Food and Drug Administration (FDA), despite their excellent efficiency 
of transfection. Insertional mutagenesis poses a significant risk with use of viral vectors that involve the integration of their nucleic cargo to the host genome. Risk of carcinogenesis is also an important concern with regards to insertional mutagenesis, albeit a low risk, whereby proto-oncogenes or genes involved in cell cycle regulation are affected resulting in tumor formation [83-86]. Immunogenicity also poses a significant barrier because viral vectors have the potential to provoke a robust immune response post administration in vivo, resulting in the need for vector modification to overcome such complications [86]. Additionally, the general lack of cost-effectiveness and the challenging nature of vector production and scale-up $[87,88]$ has seen a seismic shift in research focus to transgene delivery using safer alternatives (e.g., non-viral vectors).

\subsection{Non-Viral Vectors}

The use of non-viral vectors for the DNA delivery for bone repair is well established and more recently these approaches are being explored for the delivery of RNA agents [89]. Non-viral vectors composed of organic or inorganic-based materials have been used successful in RNA-based therapies. Polyethylenimine (PEI) have been widely studied as non-viral vectors for gene delivery, however high molecular weight PEI is highly toxic to cells and low molecular weight PEI has low transfection efficiencies [22]. As a result, PEI has been combined with other polymers offering improved biocompatibility. Specific combinations include the following PEI/poly(lactic-co-glycolic acid) (PLGA) [90] and PEI/poly(ethylene)glycol (PEG) [22]. Chitosan [91]) and cationic lipids (e.g., Lipofectamine ${ }^{\circledR} 2000$ [22,92], aptamer-functionalized lipids [93] and 1,2-Dioleyl-3-trimethylammonium-propane (DOPA) [94]) have also shown promise in this regard [95]. Inorganic vectors include calcium phosphate (CaP) [96,97], bioactive glass [98,99], carbon nanotubes [100], silica [101], and gold [102]. Non-viral vectors confer a range of advantages over their viral counterparts: they can deliver larger genetic cargos, have reduced immunogenicity/toxicity and are easier to construct and modify [103]. The application of non-viral vectors also allows delivery of synthetic siRNA/miRNA mimics, thereby avoiding the need for nuclear localization as per pDNA constructs containing RNAi expression cassettes. This action enables the direct interaction of siRNA/miRNA with RNAi machinery in the cytosol, reducing the extent of the intracellular trafficking required for RNAi mediated gene repression and silencing. However, despite these benefits, a significant barrier exists between non-viral vectors and their approved clinical usage due primarily to their poor transfection efficiency [103]. Other concerns relate to undesirable off-target or on-target effects, short half-life under physiological conditions and the potential for an unfavorable immune response. This review focusses specifically on the use of calcium phosphate nanoparticles for RNA delivery for bone-related conditions, and the various surface modifications and functionalization strategies that can be employed to ensure effective targeted delivery.

\section{Calcium Phosphates Nanoparticles as Non-Viral Vectors}

The natural occurrence of calcium phosphate within the body, specifically in bone and tooth enamel, makes them a logical choice for RNA delivery for bone repair applications [2]. $\mathrm{Ca}^{2+}$ and $\mathrm{PO}_{4}^{3-}$ ions play a critical role in the regulation of bone resorption and bone deposition [104]. In particular, $\mathrm{Ca}^{2+}$ is shown to actively induce chemotaxis, attracting cells such as monocytes, osteoblasts, and hematopoietic stem cells to the site of injury [105]. $\mathrm{Ca}^{2+}$ is also shown to induce proliferation and osteoblast differentiation [106], along with the expression of osteogenic genes [107]. Similarly, $\mathrm{PO}_{4}^{3-}$ is involved in osteoblast proliferation and differentiation [108] via entering the mitochondria and stimulating the production of adenosine triphosphate (ATP), which converts to adenosine and promotes osteogenesis $[109,110]$. Furthermore, calcium phosphate nanoparticles have specific properties that make them attractive as delivery vectors for RNA. Calcium phosphate has a high binding affinity to various molecules including RNA, with binding occurring through electrostatic interaction between $\mathrm{Ca}^{2+}$ in the CaP carrier and phosphate groups in the RNA structure [2]. Calcium phosphate is easily endocytosed by cells through the lipid bilayer cellular membrane and dissolves within the acidic 
environment in endosomes and lysosomes leading to the release of nucleic acid in the targeted region within the cell [111]. Calcium phosphate nanoparticles are biocompatible, biodegradable, non-toxic and non-immunogenic [111]. Additionally, calcium phosphate nanoparticles have demonstrated improved cytocompatibility compared to Lipofectamine ${ }^{\mathrm{TM}_{2}} 200$ thus suggesting a better applicability in vivo [112]. Calcium phosphate nanoparticles also demonstrate osteogenic properties that make them particularly attractive as non-viral vectors for bone tissue engineering applications [113,114]. The use of calcium phosphate nanoparticles as non-viral delivery vectors has also been shown to promote enhanced osteogenic differentiation of bone marrow-derived MSCs compared to PEI [115]. Furthermore, calcium phosphate-based powders are inexpensive and easily synthesized nanocarriers and a high level of safety relating to the use of calcium phosphate nanoparticles for cell transfection has been reported $[74,75,116]$.

The use of calcium phosphate for gene delivery was first demonstrated by Graham and Van der $\mathrm{Eb}$ [117]. They realized that producing calcium phosphate in a DNA rich aqueous solution would lead to the spontaneous formation of nano-sized DNA loaded calcium phosphate without interfering with the calcium phosphate structure [117]. Since the application of high energy methods, such as the use of high temperature or high shear stress, has the potential to degrade the genetic cargo quickly, the main route for synthesizing calcium phosphate nanoparticles for gene delivery is the wet co-precipitation method [118]. Control over the main reaction parameters (e.g., temperature, $\mathrm{pH}$, reaction time and precursor concentrations) is important to enable optimization of the particle properties for gene delivery applications and to ensure reproducibility [11]. Welzel et al. reported the use of a controlled wet-precipitation method for the synthesis of spherical DNA loaded calcium phosphate nanoparticles with a mean particle size of 10-20 nm [119]. A similar methodology was used by Mencía Castaño et al. to fabricate nHA particles complexed with both miR-mimics and antagomiRs forming nanomiRs [33,96,97].

The family of calcium phosphate-base materials is commonly characterized based upon chemical composition, crystallinity, and morphology [120]. The solubility of calcium phosphates is determined by their $\mathrm{Ca} / \mathrm{P}$ ratio, crystallinity, phase purity and the $\mathrm{pH}$ of the local environment, with pure crystalline HA exhibiting the highest $\mathrm{Ca} / \mathrm{P}$ ratio and least solubility in a physiological environment leading to slower resorption kinetics in vivo [2,120,121]. To be successful as a vector for RNA delivery it is necessary for calcium phosphate particles to remain stable within the hostile extracellular environment in order to protect the molecular cargo. Once inside the cell, transfection efficiency is dependent on the ability of RNA to escape from the endosome. Since endosomal escape is directed by the dissolution behavior of the carrier, faster dissolution leads to a faster increase in osmotic pressure and thus earlier endosome escape [122]. Calcium phosphate nanoparticles thus have particular advantages for RNA delivery since nanoparticle dissolution can be triggered by the acidic environment found inside the cell and thus extracellular liberation of the delivery cargo can be prevented. The release of the genetic cargo from endocytosed calcium phosphate nanoparticles relies on the ability of calcium phosphate to dissolve efficiently in the acidic environment within the endosome [123]. Ruvinov et al. demonstrated that the $\mathrm{pH}$ dependent reversibility of the RNA-calcium phosphate complex can be exploited for beneficial endosomal escape [124]. They proposed that the local environment with high calcium concentration formed inside the endosome due to the uptake of calcium-siRNA complexes, could lead to highly increased proton influx into the endosome. This will then lead to passive entrance of chloride ions and water molecules causing osmotic swelling, endosomal membrane rupture and escape of its contents. This calcium efflux could promote the destabilization and decomplexation of calcium-siRNA structures, leaving the siRNA to act freely in the cytoplasm upon endosomal rupture. The excess of calcium ions inside the cell could then be promptly removed by calcium pumps on the cell membrane [124]. Goldshtein et al., have also confirmed that $\mathrm{Ca}^{2+}$ ions detach from the siRNA once in the endosomal acidic environment, escaping from the endosome and allowing protons to enter, leading to swelling and eventual rupture of the early endosome [125]. 
While dissolution of calcium phosphate nanoparticles is essential in order to achieve release of the genetic cargo, high intracellular $\mathrm{Ca}^{2+}$ levels released during calcium phosphate dissolution can lead to cell death [2]. Thus consideration of both the size and solubility of calcium phosphate nanoparticles is important in order to minimize cytotoxic effects on cells $[121,126]$. While HA remains the most frequently used calcium phosphate in gene delivery applications to date, amorphous calcium phosphate (ACP), beta tricalcium phosphate and dicalcium phosphate dihydrate (DCPD) have also shown promise [122,127]. There is significant scope for investigation of other calcium phosphate phases and the development of biphasic calcium phosphate-based materials that are specifically designed with tailored resorption kinetics for effective delivery of RNA [128]. Additionally, the substitution of ions such as $\mathrm{Mg}^{2+}, \mathrm{CO}_{2}{ }^{3}, \mathrm{~K}^{+}, \mathrm{Sr}$ and $\mathrm{Al}^{3+}$, into the calcium phosphate crystal lattice has been shown to result in enhanced cellular uptake and thus may lead to increased efficiencies of RNA delivery [111,129-131].

The mean particle size, shape and charge are pivotal parameters for ensuring that calcium phosphate nanoparticles loaded with genetic material can be internalized by cells. Adair et al. report that intracellular internalization requires positively charged particles of less than $200 \mathrm{~nm}$ in size [132]. Olton et al. report the ideal calcium phosphate particle size for non-viral gene delivery to be between 25 and $50 \mathrm{~nm}$ [133]. Dorozhkin reported similar results demonstrating that calcium phosphate nanoparticles exhibiting a mean particle size of $20 \pm 5 \mathrm{~nm}$ result in the most significant cellular uptake by osteoblast-like cell lines [12]. Regarding shape-porous, sphere-like nanoparticles are recognized as being preferable not only for gene delivery but also for cell targeting and drug loading [134]. Studies have shown that spherical calcium phosphate nanoparticles can increase osteoblastic proliferation [126] and osteogenic gene expression [135], and limit cell apoptosis [136]. The sizeable surface-area-to-volume ratio offered by calcium phosphate nanoparticles can be exploited to maximise drug loading for therapeutic applications [137]. Recently, mesoporous calcium phosphate nanoparticles $(2-50 \mathrm{~nm})$ have received significant attention because of their increased surface area which could potentially be exploited to enhance drug delivery and RNAi encapsulation [138].

The zeta potential or surface charge of calcium phosphate nanoparticles is another crucial parameter for nanoparticle gene delivery as it determines whether the nanoparticle can pass through the cell membrane. Positively charged nanoparticles reportedly result in a higher cellular uptake [139]. However, it is difficult to compare the effect of zeta potential across different studies, as the surface charge is highly sensitive to various sintering routes, different functionalization and experimental conditions [139]. In order to investigate the influence of nanoparticles with differing zeta potential while maintaining the same size and shape, Chen et al. studied the cellular uptake of three compositions of HA nanoparticles that were functionalized with carboxylic acids with the variant of one different functional group [140]. Their work confirmed that positively charged HA nanoparticles are more biocompatible and exhibit a more sustained cellular uptake [140]. Furthermore, the electrostatic interaction between surface charge and adsorbed proteins is dependent on the zeta potential of the calcium phosphate nanoparticles, which is influenced by $\mathrm{pH}$, ionic strength and $\mathrm{Ca}^{2+}$ and $\mathrm{PO}_{4}{ }^{3-}$ ion concentrations [141].

Despite the advantages of calcium phosphate for RNAi delivery, challenges remain. Firstly, the stability of calcium phosphate nanoparticles is limited due to their crystal growth over time [2]. A number of approaches have been investigated to overcome this. Mencía Castaño et al. used surfactant stabilized non-aggregating HA nanoparticles to deliver miR-mimics and antagomiRs [96]. They report internalization efficiencies of 17.4 and $36.5 \%$ for miR-mimics and antagomiRs, respectively, with both yielding sustained interfering activity of greater than $90 \%$ in monolayer over seven days [96]. This approach was further applied in the delivery of miR-133a inhibiting complexes [33] and antagomiR-16 [97] to enhance human stem cell-mediated osteogenesis. An alternative approach involves the substitution of magnesium $\left(\mathrm{Mg}^{+}\right)$into the calcium phosphate structure during the co-precipitating reaction leading to a distortion of the atomic structure that inhibits particle growth [142]. Chowdhury report a ten-fold increase in transfection following the incorporation of $\mathrm{Mg}^{+}$into calcium phosphate particles when compared to calcium phosphate alone [129]. However, contradictory results 
were reported by Goldshtein et al., who suggested that the higher intracellular concentration of $\mathrm{Mg}^{2+}$ would impede the cellular uptake of $\mathrm{Mg}^{2+}$ doped calcium phosphate [125].

The protection of the genetic cargo from nuclease disruption is a further essential consideration that impacts on the transfection efficiency when using calcium phosphate nanoparticles for gene delivery. Different approaches have been investigated in order to further improve the protection of the genetic cargo and control its rate of release, including the incorporation of genetic material within the core of the calcium phosphate nanoparticle [143] or the use of multi-shell calcium phosphate nanoparticles [2]. The latter configuration provides a much slower degradation profile and further preservation of the genetic cargo [2]. Sokolova et al. successfully developed an approach, which involved preparing a double layer coating of calcium phosphate nanoparticles and DNA, showing an increased transfection efficiency compared to a single layer coating [144]. Multi-shell nanoparticles also allow for a more sustained controlled release and longer storage time of 2-3 months [145]. Tenkumo et al. fabricated multi-shell nanoparticles, by combining HA with functionalized pDNA, which was subsequently loaded in a collagen scaffold for periodontal tissue repair. These functionalized collagen scaffolds exhibited a higher transfection efficacy compared to Lipofectamine ${ }^{\circledR} 2000$, a widely used commercial available transfection agent [146].

Overall, the goal for successful delivery of RNA using calcium phosphate nanoparticles is to ensure that: (i) the nanoparticles adhere to the cell membrane without being washed away, (ii) once adhered, the nanoparticles and RNA cargo remain stable for a sufficient amount of time to enable them to be endocytosed by the targeted cells, and (iii) the nanoparticles can escape from the endosome into the cytoplasm in order to activate the RNAi response. Even though the use of calcium phosphate nanoparticles for RNAi delivery has been shown to promote bone repair efficiently, transfection efficiency remains low in comparison to that achieved using viral vectors. Therefore, significant research has been conducted to investigate the influence of surface functionalization of calcium phosphate to facilitate endocytosis of calcium phosphate-based carriers and the consequent endosomal escape [147].

\section{Functionalized Calcium Phosphate Nanoparticles for Delivery of miRNAs}

The functionalization of calcium phosphate nanoparticles, through the use of PEG-ylation [148], cationic polymer [149], natural polymers [150], biodegradable lipids [151] and cell-penetrating peptides [152] (Figure 3), has been shown to enhance cellular uptake and improve transfection efficiency in gene delivery for a range of applications $[111,118,153,154]$. While calcium phosphate functionalization methods have not been widely used in date in RNA-based therapies for bone regeneration, they hold significant promise in this regard. The advantages and limitations of these surface functionalization methods are outlined in Table 2. 


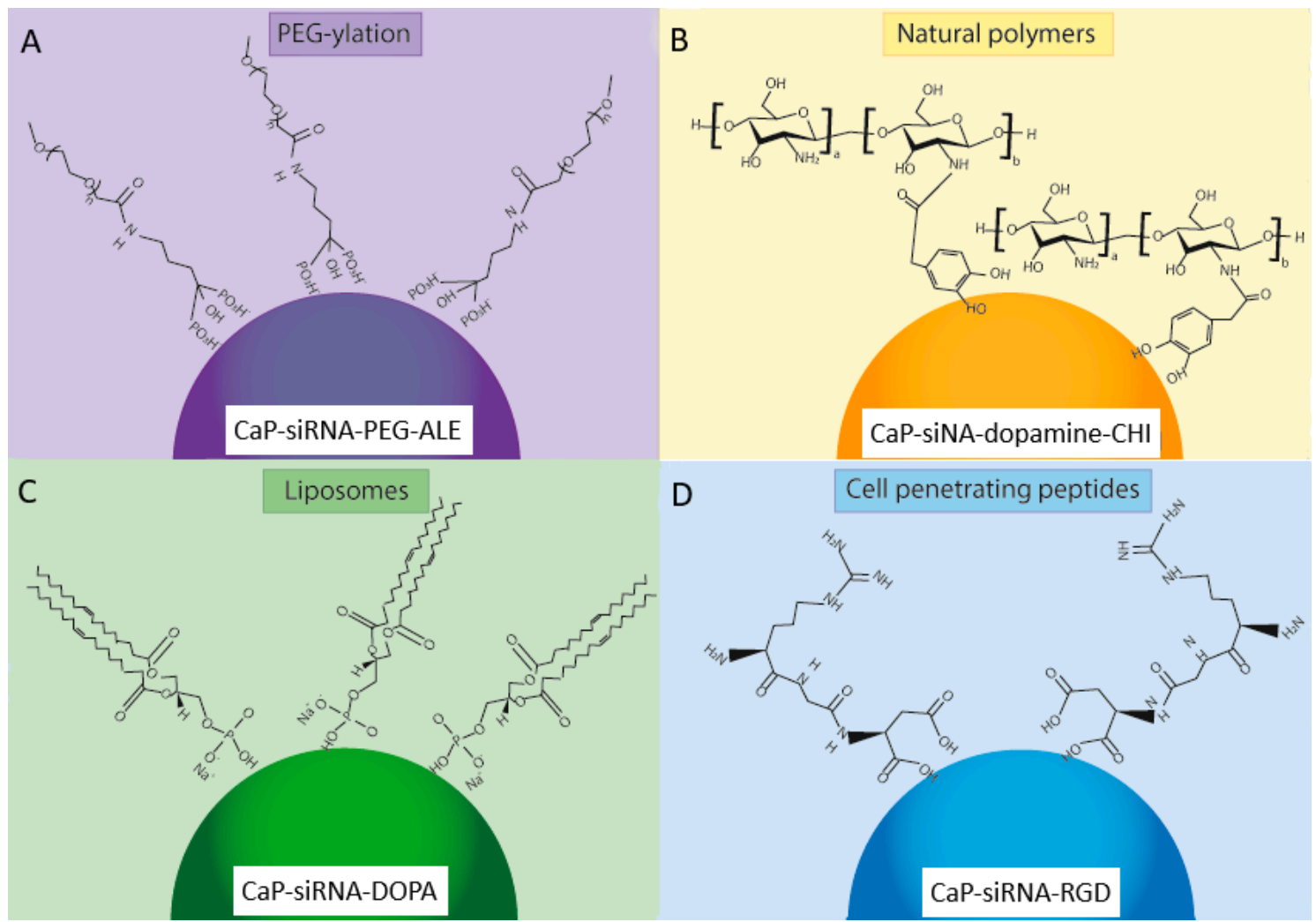

Figure 3. The main methods for surface functionalization of CaP nanoparticles loaded with genetic material (RNAi): (A) PEG-ylation, (B) Natural polymers, (C) Liposomes, (D) Cell penetrating peptides. One example of each surface functionalization method is shown. PEG-ylation using PEG and alendronate (PEG-ALE) is shown in (A) [155], the natural polymers chitosan and dopamine (-CHI) are shown in (B) [156], the use of the liposome 1,2-Dioleoyl-sn-glycero-3-phosphate (DOPA) lipid is shown in (C) [157], and the cell penetrating peptide Arginine-Glycine-Aspartic acid (RGD) is shown in (D) [74]. 
Table 2. Advantages and limitations of calcium phosphate nanoparticle surface functionalisation methods.

\begin{tabular}{|c|c|c|c|c|c|}
\hline $\begin{array}{c}\text { Surface } \\
\text { Functionalisation } \\
\text { Method }\end{array}$ & Advantages & Limitations & Examples & Particle Size (Mean nm) & Transfection Efficiencies (\%) \\
\hline PEG-ylation & $\begin{array}{ll}\text { - } & \text { Improves calcium } \\
\text { phosphate particle stability } \\
\text { preventing particle growth } \\
\text { - } \quad \text { Enhances particle protection } \\
\text { allowing increased } \\
\text { circulation time } \\
\text { - Improves biocompatibility } \\
\text { - Low immunogenicity } \\
\text { - Low cytotoxicity }\end{array}$ & $\begin{array}{l}\text { Inhibits cellular uptake } \\
\text { and endosomal escape }\end{array}$ & $\begin{array}{ll}\text { - } & \text { PEG-ALE coated } \\
& \text { CaP-siRNA [155] } \\
\text { - } & \text { PAsp(DET)-PEG-siRNA-CaP } \\
& \text { [158] } \\
\text { - } & \text { CaP/PEG-PAA/siRNA [159] } \\
\text { - } & \text { PEG-SS-siRNA/CaP [160] }\end{array}$ & $\begin{array}{ll}\cdot & 260 \\
- & 42 \pm 5 \\
- & 100-300 \\
- & 90-120\end{array}$ & $\begin{array}{ll}\text { - } & \text { Not provided } \\
\text { - } & \sim 82 \\
\text { - } & \sim 95 \\
& 76-86\end{array}$ \\
\hline Cationic polymers & $\begin{array}{ll}\text { - } & \text { Increases } \\
\text { transfection efficacy } \\
\text { - } \quad \text { Increases calcium } \\
\text { phosphate stabilization }\end{array}$ & $\begin{array}{l}\text { - Mostly non-degradable } \\
\text { - Cytotoxic }\end{array}$ & $\begin{array}{ll}\bullet & \text { siRNA-CaP-PEI [149] } \\
\text { CaP-siRNA-tyrosine-grafted } \\
\text { PEI (PEIY) [161] }\end{array}$ & $\begin{array}{ll}\cdot & 316 \pm 51 \\
\bullet & 56-60\end{array}$ & $\begin{array}{ll}-\quad \sim 70 \\
\bullet \quad \sim 95\end{array}$ \\
\hline Natural polymers & $\begin{array}{ll}\text { - } & \text { Excellent biocompatibility } \\
\text { - } & \text { Biodegradable } \\
\text { - } & \text { Low toxicity }\end{array}$ & $\begin{array}{ll}\text { - } & \text { Low } \\
\text { transfection efficiency } \\
\text { - } & \text { Poor stability after } \\
& \text { cellular uptake }\end{array}$ & $\begin{array}{l}\text { CaP-siRNA-chitosan-glutamine } \\
\text { [162] } \\
\text { CaP/siRNA/DOPA-chitosan } \\
\text { [156] } \\
\text { CaP/siRNA/DOPA-hyaluronic } \\
\text { acid [150] } \\
\text { DOPA-hyaluronic } \\
\text { acid/CaP/DNA/miRNA } \\
\text { [163] }\end{array}$ & $\begin{array}{ll}\text { e } & \\
\text { - } & 119 \\
\text { - } & 131.0 \pm 2.1 \\
\text { - } & 63 \text { to } 278 \\
\text { - } & \sim 50-250\end{array}$ & $\begin{array}{ll}- & 91 \pm 6 \\
\bullet & \sim 55 \\
\bullet & 45-70 \\
- & 99.9\end{array}$ \\
\hline Cationic liposomes & $\begin{array}{l}\text { - Increases calcium } \\
\text { phosphate stabilization }\end{array}$ & $\begin{array}{ll}\text { - } & \text { Cytotoxic } \\
\text { - } & \text { Inflammatory response } \\
\text { - } & \text { Early removal by the } \\
& \text { phagocyte system }\end{array}$ & $\begin{array}{l}\text { - Lipid calcium phosphate } \\
\text { nanoparticles [164] }\end{array}$ & - $\quad \sim 40$ & - $\quad \sim 91$ \\
\hline $\begin{array}{l}\text { Cell-penetrating peptides } \\
\text { (CPPs) }\end{array}$ & $\begin{array}{ll}\text { - } & \text { Enhances direct delivery } \\
\text { through the cell membrane } \\
\text { - } & \text { Increases calcium } \\
\text { phosphate stabilization } \\
\text { - } & \text { Increases } \\
\text { transfection efficiency }\end{array}$ & $\begin{array}{l}\text { - } \quad \text { Rapid degradation by } \\
\text { enzymes within } \\
\text { body fluids }\end{array}$ & $\begin{array}{l}\text { - } \\
\text { Arginine CPP CaP-siRNA } \\
\text { Arginine-alanine-leucine-alanine } \\
\text { (RALA)-CaP [165] }\end{array}$ & $\begin{array}{ll}\bullet & 95-171 \mathrm{~nm} \\
\mathrm{ne} & >100 \mathrm{~nm}\end{array}$ & $\begin{array}{ll}- & \text { Not provided } \\
\text { - } & \text { Not provided }\end{array}$ \\
\hline
\end{tabular}




\subsection{PEG-Ylation}

Poly-ethylene-glycol (PEG) is a hydrophilic polymer that prevents nanoparticle agglomeration by inhibiting particle growth and increases calcium phosphate biocompatibility by decreasing non-specific protein absorption in vivo, which would degrade the RNAi cargo [166]. The use of a PEG shell also helps to minimize the calcium ion release from calcium phosphate following enzymatic degradation in the cytosol, further increasing the biocompatibility of calcium phosphate nanoparticles [111]. Zhang et al. suggested that the thickness of the PEG shell can affect cellular uptake, and proposed an optimal thickness of $10 \mathrm{~nm}$ [160]. PEG can be used in conjunction with chelators to further improve its efficacy in stabilizing calcium phosphate nanoparticles, thereby increasing its biocompatibility. Bisphosphonates present a strong affinity for the HA embedded within the bone mineral phase, which confers them with high bone tissue specificity [167]. Therefore, bisphosphonates are widely used in the treatment of various bone diseases (e.g., osteoporosis, Paget's disease and osteosarcoma). Giger et al. successfully synthesized PEG-bisphosphonate-DNA-calcium phosphate nanoparticles demonstrating a mean particle size of $200 \mathrm{~nm}$, zeta potential of $-20 \mathrm{mV}$, and polydispersity index (PDI) of 0.2-0.3 [168]. These PEG-bisphosphonate-DNA-CaP nanoparticles were stable over $72 \mathrm{~h}$, proving the positive effect of surface functionalization in preventing particle agglomeration. Giger et al. reported $\geq 60 \%$ transfection efficacy comparable to Lipofectamine ${ }^{\circledR} 2000$, while maintaining cell viability of about $90 \%$ at bisphosphonate concentrations lower than $10 \mu \mathrm{M}$, thereby alleviating concerns associated with cytotoxicity of bisphosphonate nanoparticles at low concentration levels [168]. Giger et al. also investigated the use of alendronate (ALE) bound to PEG, which formed a PEG-ALE complex (Figure 3A). The calcium phosphate-siRNA nanoparticles maintained a similar mean particle size (i.e., $260 \mathrm{~nm}$ ), zeta potential of $-17 \mathrm{mV}$ and were stable for over one month, which facilitated good transfection efficacy via clathrin-dependent endocytosis [155]. They also suggested that acidification of the endosome is needed for RNAi cargo release, and highlighted that $\mathrm{pH}$ control is crucial for endosomal escape.

pH-responsive calcium phosphate nanoparticles containing a disulphide bond between PEG and siRNA were developed by Zhang et al. [160]. These nanoparticles demonstrated instability when inserted into a reducing environment such as cytosol, allowing for effective cargo release. The use of a disulphide bond also enhanced siRNA uptake by avoiding disruptive interaction between PEG and siRNA [160]. The resultant nanoparticles exhibited a mean particle size of $100 \mathrm{~nm}$ and a PDI $\leq 0.1$, confirming the ability of PEG to inhibit calcium phosphate particle growth [160]. Charge conversional polymers pass from anionic to cationic in the presence of low $\mathrm{pH}$, hence facilitating the endosomal escape of the RNAi cargo. Pittella et al. achieved a rapid siRNA release by grafting 1,2-diaminoethane side chain poly\{N-[N'-(2-aminoethyl)-2-aminoethyl] aspartamide\}, also known as PAsp(DET), with PEG-siRNA-CaP. PAsp(DET) is a good candidate for $\mathrm{pH}$-responsive calcium phosphate nanoparticles because of the protonation behavior of its side chain, which leads to $\mathrm{pH}$-selective membrane destabilization and its biodegradability in physiological conditions [158]. This PAsp(DET)-PEG-siRNA-calcium phosphate approach showed promising results in vivo [169]. Similarly, Lee et al. used citraconic anhydride to graft on PEGylated calcium phosphate to obtain a $\mathrm{pH}$-sensitive surface functionalization of calcium phosphate nanoparticles [170]. Further research in this area has focused on calcium phosphate functionalization using a PEG and poly-aspartic acid (PEG-PAA) copolymer [159]. The resultant calcium phosphate nanoparticles exhibited a mean particle size of $140 \mathrm{~nm}$, and the particle size was reported to be inversely proportional to the amount of PEG-PAA used [171,172]. Kakizawa et al. reported that functionalizing the calcium phosphate-siRNA nanoparticles with PEG-PAA obtained a significant improvement in transfection efficacy showing up to $60 \%$ silencing, which confirmed the successful release of siRNA into the cytoplasm [159]. However, the use of PEG-ylation has often raised challenges regarding cellular uptake and endosomal escape, known as 'PEG dilemma' [173]. Several approaches have been investigated to overcome this hurdle, including adding specific ligands to target the desired cells, introducing cleavable PEG systems, and investigating ways to readily disrupt the endosomal barrier to free the cargo [173]. 


\subsection{Cationic Polymers}

Polyethylenimine (PEI) is a hydrophilic polymer, widely used both on its own and in conjunction with other materials as a non-viral vector for cell transfection due to its favorable chemistry. PEI is primarily composed of $25 \%$ of primary amines, $50 \%$ secondary amines and $25 \%$ tertiary amines. Of these amines, the great majority are protonated under in vivo conditions [166]. The non-protonated amines act as a buffer over a wide range of $\mathrm{pH}$ and allow for endosomal escape of the genetic cargo. Due to its high amine density, once endocytosed, PEI-encapsulated materials require ATPase enzyme to transport a high number of protons to reach the desired acidification of the endosome, causing an increase in osmotic swelling and subsequent rupture of the endosome; thereby releasing the PEI-encapsulated material [154]. As such, PEI has been used for surface functionalization of calcium phosphate nanoparticles as an outer layer, even though calcium phosphate functionalized with untreated PEI tends to be unstable [161]. This instability causes the formation of nanoparticle agglomerates once in a cellular environment [161]. Neuhaus et al. prepared triple shell calcium phosphate-siRNA-CaP-PEI to increase calcium phosphate stabilization and transfection efficacy, where the outer PEI shell provided a positive charge and calcium phosphate colloidal stability [149]. The nanoparticles demonstrated a mean particle size $\leq 100 \mathrm{~nm}$, a PDI of $0.2-0.3$, and zeta potential of $16 \mathrm{mV}$. The measured transfection efficacy was comparable to Lipofectamine ${ }^{\circledR} 2000$, and cell viability remained $\geq 80 \%$, which demonstrated the calcium phosphate-siRNA-CaP-PEI nanoparticles were moderately cytotoxicity [149]. Devarasu et al. prepared calcium phosphate-siRNA coated nanoparticles using tyrosine-grafted PEI (PEIY) [161]. These calcium phosphate-siRNA nanoparticles demonstrated a mean particle size of $60 \mathrm{~nm}$, a zeta potential of $24-30 \mathrm{mV}$, and were stable for up to six days [161]. The in vitro transfection showed a silencing efficacy of $95 \%$, and galactose moiety addition to the PEIY coating enhanced the interactions with galactose receptors on hepatocyte and Kupffer cells within the liver leading to improved particle biodistribution in vivo, without affecting the size, stability and in vitro efficiency of the calcium phosphate-siRNA nanoparticles [161].

However, PEI usage is limited because of cytotoxic concerns due to its high charge density. Linear PEI shows higher transfection efficiency and lower cytotoxicity compared to branched PEI and is therefore the preferred option for in vivo applications even though it exhibits lesser amine binding sites [166]. Consequently, PEI modification with PEG grafting is the most common approach to overcome issues associated with cytotoxicity. Petersen et al. reported the degree of substitution for PEI-PEG polymers strongly decreased PEI cytotoxicity and was independent of PEG molecular weight [174]. However, the molecular weight of PEG affected the ability of PEG-PEI copolymers to condense the genetic cargo. PEG with a molecular weight of $5 \mathrm{kDa}$ resulted in the formation of spherical nanoparticles demonstrating a mean particle size of $60 \mathrm{~nm}$, whereas a lower molecular weight PEG (550 Da) resulted in a significant increase in mean particle size of $130 \mathrm{~nm}$ [174].

Another cationic polymer used for the surface functionalization of calcium phosphate to enhance cargo release is poly(lactic-co-glycolic acid) (PLGA), which is composed of lactic acid and glycolic acid connected by ester bonding [175]. Wang et al. reported the functionalization of calcium phosphate-pDNA using PLGA-Mpeg for delivery of sizeable genetic cargo. The resultant nanoparticles exhibited a particle size ranging from $20-60 \mathrm{~nm}$ and remained highly stable in aqueous solution [176]. Similarly, Tang et al. produced calcium phosphate-pDNA-PLGA nanoparticles that demonstrated a mean particle size of $200 \mathrm{~nm}$ and the encapsulation of $95 \%$ of pDNA [175]. The transfection efficacy with this approach was relatively low (22\%); however, it was significantly improved when compared to that of PLGA-pDNA or calcium phosphate-pDNA nanoparticles [175].

The potential of a triple shell calcium phosphate/siRNA/calcium phosphate/PEI for siRNA delivery for knocking down tumor necrosis factor alpha (TNF- $\alpha$ ) in the treatment of tumor cells was investigated by Neuhaus et al. [149]. They successfully reduced gene expression to $18 \%$ of the original value, while cell viability remained $\geq 70 \%$ [149]. Zhang et al. also investigated the synthesis of triple shell calcium phosphate nanoparticles in conjunction with siRNA and poly-(L-lysine) embedded in a multi-layered electrolyte film and achieved strong silencing of the OCN and OPN gene expressions on human 
osteoblasts thus the ability to control bone formation using these novel nanoparticles was confirmed and their potential for use in bone tissue engineering applications demonstrated [177].

\subsection{Natural Polymers}

Natural polymers, including chitosan [162,178] and hyaluronic acid [150,163], have also been used for the surface functionalization of calcium phosphate nanoparticles for gene therapy in bone tissue engineering applications. Chitosan is a natural polysaccharide that offers excellent biocompatibility and biodegradability [162]. It contains many carboxyl groups that can effectively control the synthesis of calcium phosphate nanoparticles by absorbing $\mathrm{Ca}^{2+}$ ions and forming chitosan/CaP nanoparticles [114]. It has a high positive charge that leads to enhanced electrostatic interactions between the primary amines within chitosan structure and the negatively charged RNA, thereby protecting RNA during cellular uptake and leading to an increase in transfection efficiency [162]. The transfection efficacy of chitosan is related to its molecular weight, the degree of deacetylation and ratio of nitrogen atoms binding to the phosphate groups of the calcium phosphate [166]. The use of chitosan-glutamine is an exciting approach to enhance calcium phosphate transfection, where high cationic glutamine is used to increase the particle charge of the calcium phosphate nanoparticles. Choi et al. confirmed stabilization of calcium phosphate-siRNA and calcium phosphate-siRNA-chitosan-glutamine nanoparticles and reported a mean particle size reduction from $443 \mathrm{~nm}$ to $119 \mathrm{~nm}$ and a decrease in PDI from 0.863 to 0.216 [162]. They subsequently loaded a siRNA targeting Noggin into the calcium phosphate nanoparticles that were delivered using a chitosan hydrogel and evaluated transfection efficacy and ALP expression in adipose tissue derived stem cells (ADSCs). Results indicated that the transfection values were comparable to Lipofectamine ${ }^{\circledR} 2000$, and ALP production was increased [162].

Surface functionalized of calcium phosphate nanoparticles with chitosan has been shown by Lee et al. to increase serum stability of calcium phosphate-pDNA nanoparticles from $4 \mathrm{~h}$ to $24 \mathrm{~h}$ (Figure 3B) [156]. Lee et al. further functionalized these nanoparticles for DNA and siRNA delivery by adding dopamine, achieving enhanced nanoparticle stability and significantly reducing the mean particle size to $130 \mathrm{~nm}$ [150]. The catechol group of the dopamine molecule was crucial to particle stabilization, acting as a bridge between the calcium ions of calcium phosphate and chitosan. The chitosan-dopamine-siRNA-calcium phosphate nanoparticles displayed enhanced target-gene silencing by siRNA when compared to the chitosan-siRNA-calcium phosphate nanoparticles [156]. Dopamine has also been used with hyaluronic acid; Lee et al. demonstrated that increasing DOPA-hyaluronic acid functionalization resulted in increased particle stability and improved protection of siRNA from enzyme-mediated digestion [150]. A further study by this group demonstrated improved osteogenic differentiation of human bone marrow-derived MSCs (hMSCs) resulting from the co-delivery of a plasmid DNA encoding bone morphogenetic protein 2 and micro RNA 148b using DOPA-hyaluronic acid/CaP [163]. They demonstrated that hyaluronic acid restricted undesirable aggregation and excessive crystal growth of the $\mathrm{CaP}$ particles and showed that DOPA-hyaluronic acid/CaP achieved significantly higher transfection in hMSCs than branched polyethylenimine (bPEI, MW $25 \mathrm{kDa}$ ) with no cytotoxicity, as a result of the specific interactions between hyaluronic acid and CD44 of bone marrow-derived hMSCs [163].

Finally, an interesting approach is calcium phosphate nanoparticle functionalization with cell targeting molecules. Kozlova et al. reported the surface modification of calcium phosphate nanoparticles for antibody targeting [179]. They prepared calcium phosphate-PEI-siRNA nanoparticles and wrapped them in a silica shell, which was further functionalized by salinization. This functionalization process introduced an amine or thiol group for antibody binding and cellular uptake was confirmed using a human osteoblast-like cell line, MG-63, demonstrating the potential of these particles for bone tissue regeneration [179]. 


\subsection{Cationic Liposomes}

Cationic liposomes used as non-viral vectors are commonly composed of fatty acids linked to an alkyl functional group, which results in a positively charged head with a hydrophobic tail [180]. Felger reported the first use of cationic liposomes for a gene delivery therapy, through the successful embedding of pDNA into cationic liposomes and demonstration of their ability to compensate for the pDNA negative charge [181]. Felger demonstrated that this complex provided better interaction with the cell membrane and allowed for greater cellular uptake [181]. Since its discovery, cationic liposomes have been widely used in gene delivery because of their high affinity for the cell membrane and ease of production. One limitation of cationic liposomes is that they tend to bind to unspecific serum proteins, which can lead to their early removal by the phagocyte system [180]. Furthermore, while cationic lipids bearing ether bonds result in better transfection, they are non-biodegradable and lead to higher cytotoxicity. Conversely, cationic lipids including ester linkers are prone to biodegradation but are less cytotoxic [182].

Cationic liposomes have been used with greater success for the surface modification of calcium phosphate nanoparticles where they have effectively achieved nanoparticle stabilization. Zhou et al. achieved colloidal stability over a 21-day period and reported a ten-fold increase in transfection efficacy using lipid-functionalized CaP when compared to calcium phosphate alone [183]. Yang et al. investigated the surface functionalization of calcium phosphate using liposomes for siRNA delivery for cancer treatment [164]. They developed a simple lipid coating for a siRNA loaded calcium phosphate nanoparticle, which was then functionalized with PEG grafting to improve siRNA delivery. In order to further enhance siRNA delivery, they developed an asymmetric lipid functionalization approach. The calcium phosphate nanoparticles were initially coated with an anionic lipid, which entrapped the siRNA within the core, and then further coated with a cationic lipid which was PEGylated to shield charge effect and linked to an anisamide ligand [164]. Yang et al. reported a 40-fold improvement in transfection efficacy in vitro and a 4-fold increase in vivo, when using this lipid-calcium phosphate vehicle compared to a lipid-protamine one [164]. Other groups have used of 1,2-Dioleoyl-sn-glycero-3-phosphate (DOPA) lipid to functionalize aqueous-core calcium phosphate nanoparticles (Figure 3C) [157]. Schmidt et al. obtained DOPA-CaP particles of 120 to $185 \pm 50 \mathrm{~nm}$ in size, with a shell thickness of 10 to $40 \mathrm{~nm}$; the size growth was controlled by adding a carboxyethylphosphate capping molecule [157]. These nanoparticles were stable for over one month, even in the presence of proteinases and appeared to be suitable for delivery of hydrophilic cargoes [157].

\subsection{Cell-Penetrating Peptides}

Cell-penetrating peptides (CPP) are short sequences of amino acids, usually composed of 5-30 units, with the characteristic of easily penetrating the cell membrane while delivering a therapeutic cargo (e.g., RNAi). Penetration of the cellular membrane using a CPP is subject to controversy as the pathways by which it enters the cell is not entirely understood. Depending on the peptide structure, cargo and experimental conditions, different penetration mechanisms have been identified in the case of significant cargoes, e.g., clathrin-dependent [184] and clathrin-independent pathways [185], lipid rafts [186], and macropinocytosis [187]. CPPs are broadly divided into three classes: (1) cationic, (2) amphipathic and (3) hydrophobic CPPs. Cationic and amphipathic CPPs have been used to functionalize calcium phosphate nanoparticles for gene delivery applications [188].

Cationic-based CPPs represent the majority of CPPs and are characterised by their high positive charge and short amino acid sequences, and are considered very efficient in crossing the cell membrane [189]. The most common cationic CPPs are TAT peptide, penetratin and poly-arginine. Of these, only poly-arginine has been explored extensively for the functionalization of calcium phosphate nanoparticles. Arginine has a guanidium head group that can bind to the negatively charged cell membrane through hydrogen bonding, which leads to cell penetration at physiological $\mathrm{pH}$ [190]. Futaki et al. reported that for arginine CPP eight positive charges are the optimal configuration for efficient delivery [187]. Arginine-rich peptides, for example the Arg-Gly-Asp peptide sequence RGD, 
have been successfully used for calcium phosphate functionalization to improve siRNA delivery (Figure 3D). Bakan et al. reported the addition of arginine CPP did not alter the mean particle size of the calcium phosphate-siRNA nanoparticles [74]. However, it did change the zeta potential of the complex from negative to positive, thereby improving the interaction with the cellular barrier [74].

Amphipathic classified CPPs are chimeric amino acid sequences and are composed of both a hydrophilic and a hydrophobic group. Based on their structure, they can be distinguished in alpha-helical, beta-sheet structure, and proline-rich amphipathic CPP [189]. The pVEC [191,192], Pep-1 [193], and RGD peptides [194] are among the most common amphipathic CPPs, though they are not widely used in conjunction with CaP nanoparticles at present. Other examples of amphipathic CPPs have been synthesized for delivery of genetic cargoes. McCarthy et al. developed a novel peptide called RALA composed of sequences of arginine-alanine-leucine-alanine [195]. They combined the GALA and KALA peptides, where the lysine group in KALA has been substituted with arginine to overcome the limitation concerning cytotoxicity for lysine [195]. They further demonstrated how the improved $\alpha$-helicity of RALA, which is $\mathrm{pH}$-responsive once the peptide reaches the endosome, can represent a tool to facilitate nucleic cargo delivery [195]. Bennett et al. have obtained promising results for the delivery of RNAi using RALA peptide both in vitro and in vivo [196]. Sathy et al. subsequently exploited the use of RALA to enhance delivery of CaP nanoparticles, proving the positive effect of RALA-CaP in stimulating osteogenic markers and facilitating mineralization both in vitro and in vivo [165]. Overall, CPPs have shown to be very useful when used to functionalize inorganic nanoparticles, and much research has been conducted into their use in modifying gold nanoparticles and quantum dots, especially for cancer and imaging applications $[190,197]$. Research associated with the functionalization of calcium phosphate nanoparticles for effective RNAi delivery for bone tissue regeneration is still in its infancy. However, amino acid functionalization of calcium phosphate nanoparticles can be beneficial for enhanced direct delivery through the cell membrane, as the use of amino acids can provide multiple binding sites for RNAi, allowing the formation of more stable compounds [198].

\section{Conclusions and Future Perspective}

Recently, the application of gene therapy for bone tissue regeneration has attracted significant attention, offering the possibility to guide cellular fate without the administration of high quantities of drugs or protein. The use of calcium phosphate nanoparticles has been shown to facilitate the delivery of miRNAs and siRNAs, through the formation of stable complexes that can efficiently be endocytosed by targeted cells, allowing for the cytoplasmic release of miRNAs and siRNAs. This feature, in tandem with the natural biocompatibility of calcium phosphate and its promotion of bone mineralization, highlights the potential use of calcium phosphate nanoparticles as non-viral vectors for the treatment of a wide variety of bone diseases. However, reduced transfection efficacy of calcium phosphate nanoparticles remains a significant barrier to their use in clinical applications. For increased therapeutic response and transfection efficacy, calcium phosphate nanoparticles must demonstrate long-term stability under physiological conditions, reduced agglomerate formation, a mean particle size $\leq 200 \mathrm{~nm}$ and positive zeta potential for better interaction with the cell membrane. Surface functionalization of calcium phosphate nanoparticles offers the potential to overcome transfection limitations through surface modification of the nanoparticle to achieve the desired physical properties. The overall goal of these surface functionalization techniques is to maximize transfection efficiency by striking the optimal balance between protection of the genetic cargo and efficient release. Of the approaches discussed here PEG-ylation has been shown to offer improved CaP is more stable due to the colloidal stability of PEG, while generally cationic liposome coating methods result in an improved transfection efficiency due to the cationic characteristics of the lipids. Novel approaches have investigated the possibility of combining more than one functionalization method, e.g., an initial surface modification process to ensure calcium phosphate stabilization and then a further surface treatment method to improve intracellular endosomal escape. The majority of research has been directed towards the 
stabilization of calcium phosphate-RNAi nanoparticles for applications within the fields of cancer and bioimaging. However, the concepts proven for such applications also have potential for bone tissue regeneration applications, since both the bonding interactions between the calcium phosphate and RNAi and the molecular interactions between the functionalized calcium phosphate surface and the cell membrane would be similar. Specifically, the application of CPP-based systems to improve calcium phosphate transfection efficiency seems extremely promising-though the underlying mechanisms of the peptide-cell interaction are not yet well understood and require further investigation.

Finally, limited clinical translation of calcium phosphate-based gene delivery is primarily due to the lack of understanding of their behavior in vivo. As bone-related disease and bone injuries are generally not life-threatening conditions, risk-benefit concerns relating to the use of gene therapy in the treatment of these conditions requires consideration. A deeper understanding of the mechanistic principles of the in vivo bone formation process is required, especially concerning the role of miRNAs and their interplay during bone physiology. Furthermore, in order to design efficacious and clinically relevant therapies, a greater understanding of the role and target of each miRNA is required, along with identification of the optimal time frame for therapeutic delivery.

Author Contributions: Conceptualization, T.J.L., S.H., N.J.D.; writing-original draft preparation, T.J.L., S.H., J.R.; writing—review \& editing, T.J.L., S.H., J.R., H.O.M., N.J.D.; supervision, T.J.L., N.J.D.; funding acquisition, T.J.L., N.J.D. All authors have read and agree to the published version of the manuscript.

Funding: This research was funded by the Irish Research Council Government Postgraduate Scholarship Award, grant number GOIPG/2016/1526).

Acknowledgments: The authors would like to acknowledge the research support provided by the Irish Research Council Government Postgraduate Scholarship Award (GOIPG/2016/1526).

Conflicts of Interest: The authors declare no conflict of interest.

\section{References}

1. Balmayor, E.R.; van Griensven, M. Gene Therapy for Bone Engineering. Front. Bioeng. Biotechnol. $2015,3,9$. [CrossRef] [PubMed]

2. Bose, S.; Tarafder, S. Calcium phosphate ceramic systems in growth factor and drug delivery for bone tissue engineering: A review. Acta Biomater. 2012, 8, 1401-1421. [CrossRef] [PubMed]

3. Walmsley, G.G.; McArdle, A.; Tevlin, R.; Momeni, A.; Atashroo, D.; Hu, M.S.; Feroze, A.H.; Wong, V.W.; Lorenz, P.H.; Longaker, M.T.; et al. Nanotechnology in bone tissue engineering. Nanomed. Nanotechnol. Biol. Med. 2015, 11, 1253-1263. [CrossRef] [PubMed]

4. Salgado, A.J.; Coutinho, O.P.; Reis, R.L. Bone tissue engineering: State of the art and future trends. Macromol. Biosci. 2004, 4, 743-765. [CrossRef] [PubMed]

5. Vo, T.T.N.; Kasper, F.K.; Mikos, A.G.A. Strategies for controlled delivery of growth factors and cells for bone regeneration. Adv. Drug Deliv. Rev. 2012, 64, 1292-1309. [CrossRef]

6. Evans, C.H.; Huard, J. Gene therapy approaches to regenerating the musculoskeletal system. Nat. Rev. Rheumatol. 2015, 11, 234-242. [CrossRef]

7. Sun, X.; Guo, Q.; Wei, W.; Robertson, S.; Yuan, Y.; Luo, X. Current progress on microRNA-based gene delivery in the treatment of osteoporosis and osteoporotic fracture. Int. J. Endocrinol. 2019, 2019, 6782653. [CrossRef]

8. Kelly, D.C.; Raftery, R.M.; Curtin, C.M.; O'Driscoll, C.M.; O’Brien, F.J. Scaffold-Based Delivery of Nucleic Acid Therapeutics for Enhanced Bone and Cartilage Repair. J. Orthop. Res. 2019, 37, 1671-1680. [CrossRef]

9. Patel, S.; Athirasala, A.; Menezes, P.P.; Ashwanikumar, N.; Zou, T.; Sahay, G.; Bertassoni, L.E. Messenger RNA Delivery for Tissue Engineering and Regenerative Medicine Applications. Tissue Eng. Part A 2019, 25, 91-112. [CrossRef]

10. D'Mello, S.; Atluri, K.; Geary, S.M.; Hong, L.; Elangovan, S.; Salem, A.K. Bone Regeneration Using Gene-Activated Matrices. AAPS J. 2017, 19, 43-53. [CrossRef]

11. Jin, L.; Zeng, X.; Liu, M.; Deng, Y.; He, N. Current progress in gene delivery technology based on chemical methods and nano-carriers. Theranostics 2014, 4, 240-255. [CrossRef] [PubMed]

12. Dorozhkin, S.V. Nanosized and nanocrystalline calcium orthophosphates. Acta Biomater. 2010, 6, 715-734. [CrossRef] [PubMed] 
13. Bohner, M.; Galea, L.; Doebelin, N. Calcium phosphate bone graft substitutes: Failures and hopes. J. Eur. Ceram. Soc. 2012, 32, 2663-2671. [CrossRef]

14. Kim, V.N. MicroRNA biogenesis: Coordinated cropping and dicing. Nat. Rev. Mol. Cell Biol. 2005, 6, 376-385. [CrossRef]

15. Bartel, D.P. MicroRNAs: Genomics, Biogenesis, Mechanism, and Function. Cell 2004, 116, 281-297. [CrossRef]

16. Bartel, D.P. MicroRNAs: Target Recognition and Regulatory Functions. Cell 2009, 136, 215-233. [CrossRef]

17. Sriram, M.; Sainitya, R.; Kalyanaraman, V.; Dhivya, S.; Selvamurugan, N. Biomaterials mediated microRNA delivery for bone tissue engineering. Int. J. Biol. Macromol. 2015, 74, 404-412. [CrossRef]

18. Cheng, V.K.-F.; Au, P.C.-M.; Tan, K.C.; Cheung, C.-L. MicroRNA and Human Bone Health. JBMR Plus 2019, 3, 2-13. [CrossRef]

19. Lam, J.K.W.; Chow, M.Y.T.; Zhang, Y.; Leung, S.W.S. siRNA Versus miRNA as Therapeutics for Gene Silencing. Mol. Ther. Nucleic Acids 2015, 4, e252. [CrossRef]

20. Jackson, A.L.; Linsley, P.S. Recognizing and avoiding siRNA off-target effects for target identification and therapeutic application. Nat. Rev. Drug Discov. 2010, 9, 57-67. [CrossRef]

21. Li, Y.; Fan, L.; Liu, S.; Liu, W.; Zhang, H.; Zhou, T.; Wu, D.; Yang, P.; Shen, L.; Chen, J.; et al. The promotion of bone regeneration through positive regulation ofangiogenic-osteogenic coupling using microRNA-26a. Biomaterials 2013, 34, 5048-5058. [CrossRef] [PubMed]

22. Zhang, X.; Li, Y.; Chen, Y.E.; Chen, J.; Ma, P.X. Cell-free 3D scaffold with two-stage delivery of miRNA-26a to regenerate critical-sized bone defects. Nat. Commun. 2016, 7, 10376. [CrossRef] [PubMed]

23. Wang, Z.; Xie, Q.; Yu, Z.; Zhou, H.; Huang, Y.; Bi, X.; Wang, Y.; Shi, W.; Sun, H.; Gu, P.; et al. A regulatory loop containing miR-26a, GSK3 $\beta$ and $\mathrm{C} / \mathrm{EBP} \alpha$ regulates the osteogenesis of human adipose-derived mesenchymal stem cells. Sci. Rep. 2015, 5, 15280. [CrossRef] [PubMed]

24. Mariner, P.D.; Johannesen, E.; Anseth, K.S. Manipulation of miRNA activity accelerates osteogenic differentiation of hMSCs in engineered 3D scaffolds. J. Tissue Eng. Regen. Med. 2012, 6, 314-324. [CrossRef] [PubMed]

25. Li, K.C.; Lo, S.C.; Sung, L.Y.; Liao, Y.H.; Chang, Y.H.; Hu, Y.C. Improved calvarial bone repair by hASCs engineered with Cre/loxP-based baculovirus conferring prolonged BMP-2 and MiR-148b co-expression. J. Tissue Eng. Regen. Med. 2017, 11, 3068-3077. [CrossRef] [PubMed]

26. Liao, Y.H.; Chang, Y.H.; Sung, L.Y.; Li, K.C.; Yeh, C.L.; Yen, T.C.; Hwang, S.M.; Lin, K.J.; Hu, Y.C. Osteogenic differentiation of adipose-derived stem cells and calvarial defect repair using baculovirus-mediated co-expression of BMP-2 and miR-148b. Biomaterials 2014, 35, 4901-4910. [CrossRef]

27. Zhou, M.; Ma, J.; Chen, S.; Chen, X.; Yu, X. MicroRNA-17-92 cluster regulates osteoblast proliferation and differentiation. Endocrine 2014, 45, 302-310. [CrossRef]

28. Luzi, E.; Marini, F.; Sala, S.C.; Tognarini, I.; Galli, G.; Brandi, M.L. Osteogenic differentiation of human adipose tissue-derived stem cells is modulated by the miR-26a targeting of the SMAD1 transcription factor. J. Bone Miner. Res. 2008, 23, 287-295. [CrossRef]

29. Ko, J.Y.; Chuang, P.C.; Ke, H.J.; Chen, Y.S.; Sun, Y.C.; Wang, F.S. MicroRNA-29a mitigates glucocorticoid induction of bone loss and fatty marrow by rescuing Runx2 acetylation. Bone 2015, 81, 80-88. [CrossRef]

30. Trompeter, H.I.; Dreesen, J.; Hermann, E.; Iwaniuk, K.M.; Hafner, M.; Renwick, N.; Tuschl, T.; Wernet, P. MicroRNAs miR-26a, miR-26b, and miR-29b accelerate osteogenic differentiation of unrestricted somatic stem cells from human cord blood. BMC Genom. 2013, 14, 111. [CrossRef]

31. Li, Z.; Hassan, M.Q.; Jafferji, M.; Aqeilan, R.I.; Garzon, R.; Croce, C.M.; van Wijnen, A.J.; Stein, J.L.; Stein, G.S.; Lian, J.B. Biological functions of miR-29b contribute to positive regulation of osteoblast differentiation. J. Biol. Chem. 2009, 284, 15676-15684. [CrossRef] [PubMed]

32. Li, Z.; Hassan, M.Q.; Volinia, S.; van Wijnen, A.J.; Stein, J.L.; Croce, C.M.; Lian, J.B.; Stein, G.S. A microRNA signature for a BMP2-induced osteoblast lineage commitment program. Proc. Natl. Acad. Sci. USA 2008, 105, 13906-13911. [CrossRef] [PubMed]

33. Menciá Castanõ, I.; Curtin, C.M.; Duffy, G.P.; O’Brien, F.J. Next generation bone tissue engineering: Non-viral miR-133a inhibition using collagen-nanohydroxyapatite scaffolds rapidly enhances osteogenesis. Sci. Rep. 2016, 6, 27941. [CrossRef] [PubMed]

34. Chen, S.; Yang, L.; Jie, Q.; Lin, Y.S.; Meng, G.L.; Fan, J.Z.; Zhang, J.K.; Fan, J.Z.; Luo, Z.J.; Liu, J. MicroRNA-125b suppresses the proliferation and osteogenic differentiation of human bone marrow-derived mesenchymal stem cells. Mol. Med. Rep. 2014, 9, 1820-1826. [CrossRef] 
35. Eskildsen, T.; Taipaleenmaki, H.; Stenvang, J.; Abdallah, B.M.; Ditzel, N.; Nossent, A.Y.; Bak, M.; Kauppinen, S.; Kassem, M. MicroRNA-138 regulates osteogenic differentiation of human stromal (mesenchymal) stem cells in vivo. Proc. Natl. Acad. Sci. USA 2011, 108, 6139-6144. [CrossRef]

36. Yan, J.; Zhang, C.; Zhao, Y.; Cao, C.; Wu, K.; Zhao, L.; Zhang, Y. Non-viral oligonucleotide antimiR-138 delivery to mesenchymal stem cell sheets and the effect on osteogenesis. Biomaterials 2014, 35, 7734-7749. [CrossRef]

37. Itoh, T.; Nozawa, Y.; Akao, Y. MicroRNA-141 and -200a are involved in bone morphogenetic protein-2-induced mouse pre-osteoblast differentiation by targeting distal-less homeobox 5. J. Biol. Chem. 2009, 284, 19272-19279. [CrossRef]

38. Qiu, W.; Kassem, M. MiR-141-3p inhibits human stromal (mesenchymal) stem cell proliferation and differentiation. Biochim. Biophys. Acta Mol. Cell Res. 2014, 1843, 2114-2121. [CrossRef]

39. Qin, Y.; Wang, L.; Gao, Z.; Chen, G.; Zhang, C. Bone marrow stromal/stem cell-derived extracellular vesicles regulate osteoblast activity and differentiation in vitro and promote bone regeneration in vivo. Sci. Rep. 2016, 6, 21961. [CrossRef]

40. Mizuno, Y.; Tokuzawa, Y.; Ninomiya, Y.; Yagi, K.; Yatsuka-Kanesaki, Y.; Suda, T.; Fukuda, T.; Katagiri, T.; Kondoh, Y.; Amemiya, T.; et al. miR-210 promotes osteoblastic differentiation through inhibition of AcvR1b. FEBS Lett. 2009, 583, 2263-2268. [CrossRef]

41. Zhang, J.; Tu, Q.; Bonewald, L.F.; He, X.; Stein, G.; Lian, J.; Chen, J. Effects of miR-335-5p in modulating osteogenic differentiation by specifically downregulating Wnt antagonist DKK1. J. Bone Miner. Res. 2011, 26, 1953-1963. [CrossRef] [PubMed]

42. Tomé, M.; López-Romero, P.; Albo, C.; Seplveda, J.C.; Fernández-Gutiérrez, B.; Dopazo, A.; Bernad, A.; González, M.A. MiR-335 orchestrates cell proliferation, migration and differentiation in human mesenchymal stem cells. Cell Death Differ. 2011, 18, 985-995. [CrossRef] [PubMed]

43. Zhang, Y.; Xie, R.L.; Croce, C.M.; Stein, J.L.; Lian, J.B.; van Wijnen, A.J.; Stein, G.S. A program of microRNAs controls osteogenic lineage progression by targeting transcription factor Runx2. Proc. Natl. Acad. Sci. USA 2011, 108, 9863-9868. [CrossRef] [PubMed]

44. Liu, H.; Sun, Q.; Wan, C.; Li, L.; Zhang, L.; Chen, Z. MicroRNA-338-3p regulates osteogenic differentiation of mouse bone marrow stromal stem cells by targeting Runx2 and Fgfr2. J. Cell. Physiol. 2014, 229, 1494-1502. [CrossRef]

45. Hupkes, M.; Sotoca, A.M.; Hendriks, J.M.; van Zoelen, E.J.; Dechering, K.J. MicroRNA miR-378 promotes BMP2-induced osteogenic differentiation of mesenchymal progenitor cells. BMC Mol. Biol. 2014, 15, 1. [CrossRef]

46. You, L.; Gu, W.; Chen, L.; Pan, L.; Chen, J.; Peng, Y. MiR-378 overexpression attenuates high glucose-suppressed osteogenic differentiation through targeting CASP3 and activating PI3k/Akt signaling pathway. Int. J. Clin. Exp. Pathol. 2014, 7, 7249-7261.

47. Kahai, S.; Lee, S.C.; Lee, D.Y.; Yang, J.; Li, M.; Wang, C.H.; Jiang, Z.; Zhang, Y.; Peng, C.; Yang, B.B. Micro RNA miR-378 regulates nephronectin expression modulating osteoblast differentiation by targeting galNT-7. PLoS ONE 2009, 4, e7535. [CrossRef]

48. Zhang, J.-F.; Fu, W.-M.; He, M.-L.; Wang, H.; Wang, W.-M.; Yu, S.-C.; Bian, X.-W.; Zhou, J.; Lin, M.C.M.; Lu, G.; et al. MiR-637 maintains the balance between adipocytes and osteoblasts by directly targeting Osterix. Mol. Biol. Cell 2011, 22, 3955-3961. [CrossRef]

49. Li, H.; Xie, H.; Liu, W.; Hu, R.; Huang, B.; Tan, Y.F.; Liao, E.Y.; Xu, K.; Sheng, Z.F.; De Zhou, H.; et al. A novel microRNA targeting HDAC5 regulates osteoblast differentiation in mice and contributes to primary osteoporosis in humans. J. Clin. Investig. 2009, 119, 3666-3677. [CrossRef]

50. Sugatani, T.; Vacher, J.; Hruska, K.A.; Dc, W.; Sugatani, T.; Vacher, J.; Hruska, K.A. A microRNA expression signature of osteoclastogenesis. Blood 2012, 117, 3648-3657. [CrossRef]

51. Franceschetti, T.; Kessler, C.B.; Lee, S.K.; Delany, A.M. MiR-29 promotes murine osteoclastogenesis by regulating osteoclast commitment and migration. J. Biol. Chem. 2013, 288, 33347-33360. [CrossRef] [PubMed]

52. Mizoguchi, F.; Murakami, Y.; Saito, T.; Miyasaka, N.; Kohsaka, H. MiR-31 controls osteoclast formation and bone resorption by targeting RhoA. Arthritis Res. Ther. 2013, 15, R102. [CrossRef] [PubMed] 
53. Krzeszinski, J.Y.; Wei, W.; Huynh, H.; Jin, Z.; Wang, X.; Chang, T.C.; Xie, X.J.; He, L.; Mangala, L.S.; Lopez-Berestein, G.; et al. MiR-34a blocks osteoporosis and bone metastasis by inhibiting osteoclastogenesis and Tgif2. Nature 2014, 512, 431-435. [CrossRef] [PubMed]

54. Zhang, J.; Zhao, H.; Chen, J.; Xia, B.; Jin, Y.; Wei, W.; Shen, J.; Huang, Y. Interferon- $\beta$-induced miR-155 inhibits osteoclast differentiation by targeting SOCS1 and MITF. FEBS Lett. 2012, 586, 3255-3262. [CrossRef]

55. Sugatani, T.; Hruska, K.A. Impaired micro-RNA pathways diminish osteoclast differentiation and function. J. Biol. Chem. 2009, 284, 4667-4678. [CrossRef] [PubMed]

56. Seeliger, C.; Karpinski, K.; Haug, A.T.; Vester, H.; Schmitt, A.; Bauer, J.S.; van Griensven, M. Five Freely Circulating miRNAs and Bone Tissue miRNAs Are Associated With Osteoporotic Fractures. J. Bone Miner. Res. 2014, 29, 1718-1728. [CrossRef] [PubMed]

57. Chen, C.; Cheng, P.; Xie, H.; Zhou, H.D.; Wu, X.P.; Liao, E.Y.; Luo, X.H. MiR-503 regulates osteoclastogenesis via targeting RANK. J. Bone Miner. Res. 2014, 29, 338-347. [CrossRef]

58. Nakamura, Y.; Inloes, J.B.; Katagiri, T.; Kobayashi, T. Chondrocyte-Specific MicroRNA-140 Regulates Endochondral Bone Development and Targets Dnpep To Modulate Bone Morphogenetic Protein Signaling. Mol. Cell. Biol. 2011, 31, 3019-3028. [CrossRef]

59. Yang, B.; Guo, H.; Zhang, Y.; Chen, L.; Ying, D.; Dong, S. MicroRNA-145 regulates chondrogenic differentiation of mesenchymal stem cells by targeting SOX9. PLoS ONE 2011, 6, e21679. [CrossRef]

60. Lin, E.A.; Kong, L.; Bai, X.H.; Luan, Y.; Liu, C.J. MiR-199a*, a bone morphogenic protein 2-responsive MicroRNA, regulates chondrogenesis via direct targeting to Smad1. J. Biol. Chem. 2009, 284, 11326-11335. [CrossRef]

61. Arriaga, M.A.; Ding, M.; Gutierrez, A.S.; Chew, S.A. The Application of microRNAs in Biomaterial Scaffold-Based Therapies for Bone Tissue Engineering. Biotechnol. J. 2019, 14, 1900084. [CrossRef] [PubMed]

62. Komori, T.; Kishimoto, T. Cbfa1 in bone development. Curr. Opin. Genet. Dev. 1998, 8, 494-499. [CrossRef]

63. Inose, H.; Ochi, H.; Kimura, A.; Fujita, K.; Xu, R.; Sato, S.; Iwasaki, M.; Sunamura, S.; Takeuchi, Y.; Fukumoto, S.; et al. A microRNA regulatory mechanism of osteoblast differentiation. Proc. Natl. Acad. Sci. USA 2009, 106, 20794-20799. [CrossRef] [PubMed]

64. Nakashima, K.; Zhou, X.; Kunkel, G.; Zhang, Z.; Deng, J.M.; Behringer, R.R.; De Crombrugghe, B. The novel zinc fingercontaining transcription factor Osterix is required for osteoblast 12 BioMed Research International differentiation and bone formation. Cell 2002, 108, 17-29. [CrossRef]

65. Chen, S.X.; Feng, J.Q.; Zhang, H.; Jia, M.; Shen, Y.; Zong, Z.W. Key role for the transcriptional factor, osterix, in spine development. Spine J. 2014, 14, 683-694. [CrossRef]

66. Kelch, S.; Balmayor, E.R.; Seeliger, C.; Vester, H.; Kirschke, J.S.; Van Griensven, M. MiRNAs in bone tissue correlate to bone mineral density and circulating miRNAs are gender independent in osteoporotic patients. Sci. Rep. 2017, 7, 15861. [CrossRef]

67. Mehier-Humbert, S.; Guy, R.H. Physical methods for gene transfer: Improving the kinetics of gene delivery into cells. Adv. Drug Deliv. Rev. 2005, 57, 733-753. [CrossRef]

68. Zelenin, A.V.; Kolesnikov, V.A.; Tarasenko, O.A.; Shafei, R.A.; Zelenina, I.A.; Mikhailov, V.V.; Semenova, M.L.; Kovalenko, D.V.; Artemyeva, O.V.; Ivaschenko, T.E.; et al. Bacterial beta-galactosidase and human dystrophin genes are expressed in mouse skeletal muscle fibers after ballistic transfection. FEBS Lett. 1997, 414, 319-322.

69. Tsunoda, S.; Mazda, O.; Oda, Y.; Iida, Y.; Akabame, S.; Kishida, T.; Shin-Ya, M.; Asada, H.; Gojo, S.; Imanishi, J.; et al. Sonoporation using microbubble BR14 promotes pDNA/siRNA transduction to murine heart. Biochem. Biophys. Res. Commun. 2005, 336, 118-127. [CrossRef]

70. Dahlhoff, M.; Grzech, M.; Habermann, F.A.; Wolf, E.; Schneider, M.R. A transgenic mouse line expressing cre recombinase in pancreatic $\beta$-cells. Genesis 2012, 50, 437-442. [CrossRef]

71. Wiese, M.; Castiglione, K.; Hensel, M.; Schleicher, U.; Bogdan, C.; Jantsch, J. Small interfering RNA (siRNA) delivery into murine bone marrow-derived macrophages by electroporation. J. Immunol. Methods 2010, 353, 102-110. [CrossRef] [PubMed]

72. Kay, M.A.; Glorioso, J.C.; Naldini, L. Viral vectors for gene therapy: The art of turning infectious agents into vehicles of therapeutics. Nat. Med. 2001, 7, 33-40. [CrossRef] [PubMed]

73. Yin, H.; Kanasty, R.L.; Eltoukhy, A.A.; Vegas, A.J.; Dorkin, J.R.; Anderson, D.G. Non-viral vectors for gene-based therapy. Nat. Rev. Genet. 2014, 15, 541-555. [CrossRef] [PubMed] 
74. Bakan, F.; Kara, G.; Cokol Cakmak, M.; Cokol, M.; Denkbas, E.B. Synthesis and characterization of amino acid-functionalized calcium phosphate nanoparticles for siRNA delivery. Colloids Surf. B Biointerfaces 2017, 158, 175-181. [CrossRef] [PubMed]

75. Lee, S.W.L.; Paoletti, C.; Campisi, M.; Osaki, T.; Adriani, G.; Kamm, R.D.; Mattu, C.; Chiono, V. MicroRNA delivery through nanoparticles. J. Control. Release 2019, 313, 80-95. [CrossRef] [PubMed]

76. Couto, L.B.; High, K.A. Viral vector-mediated RNA interference. Curr. Opin. Pharmacol. 2010, 10, 534-542. [CrossRef] [PubMed]

77. Yokota, T.; Sakamoto, N.; Enomoto, N.; Tanabe, Y.; Miyagishi, M.; Maekawa, S.; Yi, L.; Kurosaki, M.; Taira, K.; Watanabe, M.; et al. Inhibition of intracellular hepatitis $C$ virus replication by synthetic and vector-derived small interfering RNAs. EMBO Rep. 2003, 4, 602-608. [CrossRef] [PubMed]

78. Moore, M.D.; McGarvey, M.J.; Russell, R.A.; Cullen, B.R.; McClure, M.O. Stable inhibition of hepatitis B virus proteins by small interfering RNA expressed from viral vectors. J. Gene Med. 2005, 7, 918-925. [CrossRef]

79. Ralph, G.S.; Radcliffe, P.A.; Day, D.M.; Carthy, J.M.; Leroux, M.A.; Lee, D.C.P.; Wong, L.-F.; Bilsland, L.G.; Greensmith, L.; Kingsman, S.M.; et al. Silencing mutant SOD1 using RNAi protects against neurodegeneration and extends survival in an ALS model. Nat. Med. 2005, 11, 429-433. [CrossRef]

80. Ma, J.; Chen, W.; Zhang, L.; Tucker, B.; Zhu, G.; Sasaki, H.; Hao, L.; Wang, L.; Ci, H.; Jiang, H.; et al. RNA Interference-Mediated Silencing of Atp6i Prevents Both Periapical Bone Erosion and Inflammation in the Mouse Model of Endodontic Disease. Infect. Immun. 2013, 81, 1021-1030. [CrossRef]

81. Khoury, M.; Courties, G.; Fabre, S.; Bouffi, C.; Seemayer, C.A.; Vervoordeldonk, M.J.; Tak, P.P.; Jorgensen, C.; Apparailly, F. Adeno-associated virus type 5-mediated intraarticular administration of tumor necrosis factor small interfering RNA improves collagen-induced arthritis. Arthritis Rheum. 2010, 62, 765-770. [PubMed]

82. Yang, S.; Hao, L.; McConnell, M.; Zhou, X.; Wang, M.; Zhang, Y.; Mountz, J.D.; Reddy, M.; Eleazer, P.D.; Li, Y.-P.; et al. Inhibition of Rgs10 Expression Prevents Immune Cell Infiltration in Bacteria-induced Inflammatory Lesions and Osteoclast-mediated Bone Destruction. Bone Res. 2013, 1, 267-281. [CrossRef] [PubMed]

83. Baum, C.; Kustikova, O.; Modlich, U.; Li, Z.; Fehse, B. Mutagenesis and Oncogenesis by Chromosomal Insertion of Gene Transfer Vectors. Hum. Gene Ther. 2006, 17, 253-263. [CrossRef] [PubMed]

84. Themis, M.; Waddington, S.N.; Schmidt, M.; Von Kalle, C.; Wang, Y.; Al-Allaf, F.; Gregory, L.G.; Nivsarkar, M.; Themis, M.; Holder, M.V.; et al. Oncogenesis Following Delivery of a Nonprimate Lentiviral Gene Therapy Vector to Fetal and Neonatal Mice. Mol. Ther. 2005, 12, 763-771. [CrossRef]

85. Hacein-Bey-Abina, S.; Von Kalle, C.; Schmidt, M.; Mccormack, M.P.; De Saint Basile, G.; Alexander, I.; Romana, S.; Radford-Weiss, I.; Gross, F.; Valensi, F.; et al. LMO2-Associated Clonal T Cell Proliferation in Two Patients after Gene Therapy for SCID-X1. Science 2003, 302, 415-419. [CrossRef]

86. Thomas, C.E.; Ehrhardt, A.; Kay, M.A. Progress and problems with the use of viral vectors for gene therapy. Nat. Rev. Genet. 2003, 4, 346-358. [CrossRef]

87. Bouard, D.; Alazard-Dany, D.; Cosset, F.-L. Viral vectors: From virology to transgene expression. Br. J. Pharmacol. 2009, 157, 153-165. [CrossRef]

88. Senior, M. After Glybera's withdrawal, what's next for gene therapy? Nat. Biotechnol. 2017, 35, 491-493. [CrossRef]

89. Tsekoura, E.K.; Remant Bahadur, K.C.; Uludag, H. Biomaterials to Facilitate Delivery of RNA Agents in Bone Regeneration and Repair. ACS Biomater. Sci. Eng. 2017, 3, 1195-1206. [CrossRef]

90. Wang, Y.; Tran, K.K.; Shen, H.; Grainger, D.W. Selective local delivery of RANK siRNA to bone phagocytes using bone augmentation biomaterials. Biomaterials 2012, 33, 8540-8547.

91. Wu, G.; Feng, C.; Hui, G.; Wang, Z.; Tan, J.; Luo, L.; Xue, P.; Wang, Q.; Chen, X. Improving the osteogenesis of rat mesenchymal stem cells by chitosan-based-microRNA nanoparticles. Carbohydr. Polym. 2016, 138, 49-58. [CrossRef] [PubMed]

92. Janko, M.; Dietz, K.; Rachor, J.; Sahm, J.; Schroder, K.; Schaible, A.; Nau, C.; Seebach, C.; Marzi, I.; Henrich, D. Improvement of Bone Healing by Neutralization of microRNA-335-5p, but not by Neutralization of microRNA-92A in Bone Marrow Mononuclear Cells Transplanted into a Large Femur Defect of the Rat. Tissue Eng. Part A 2018, 25, 55-68. [CrossRef] [PubMed]

93. Liang, C.; Guo, B.; Wu, H.; Shao, N.; Li, D.; Liu, J.; Dang, L.; Wang, C.; Li, H.; Li, S.; et al. Aptamer-functionalized lipid nanoparticles targeting osteoblasts as a novel RNA interference-based bone anabolic strategy. Nat. Med. 2015, 21, 288-294. [CrossRef] [PubMed] 
94. Li, J.; Yang, Y.; Huang, L. Calcium phosphate nanoparticles with an asymmetric lipid bilayer coating for siRNA delivery to the tumor. J. Control. Release 2012, 158, 108-114. [CrossRef]

95. Morille, M.; Passirani, C.; Vonarbourg, A.; Clavreul, A.; Benoit, J.P. Progress in developing cationic vectors for non-viral systemic gene therapy against cancer. Biomaterials 2008, 29, 3477-3496. [CrossRef]

96. Castaño, I.M.; Curtin, C.M.; Shaw, G.; Mary Murphy, J.; Duffy, G.P.; O’Brien, F.J. A novel collagen-nanohydroxyapatite microRNA-activated scaffold for tissue engineering applications capable of efficient delivery of both miR-mimics and antagomiRs to human mesenchymal stem cells. J. Control. Release 2015, 200, 42-51. [CrossRef]

97. Mencía Castaño, I.; Curtin, C.M.; Duffy, G.P.; O’Brien, F.J. Harnessing an Inhibitory Role of miR-16 in Osteogenesis by Human Mesenchymal Stem Cells for Advanced Scaffold-Based Bone Tissue Engineering. Tissue Eng. Part A 2019, 25, 24-33. [CrossRef]

98. El-Fiqi, A.; Kim, T.H.; Kim, M.; Eltohamy, M.; Won, J.E.; Lee, E.J.; Kim, H.W. Capacity of mesoporous bioactive glass nanoparticles to deliver therapeutic molecules. Nanoscale 2012, 4, 7475-7488. [CrossRef]

99. Xue, Y.; Guo, Y.; Yu, M.; Wang, M.; Ma, P.X.; Lei, B. Monodispersed Bioactive Glass Nanoclusters with Ultralarge Pores and Intrinsic Exceptionally High miRNA Loading for Efficiently Enhancing Bone Regeneration. Adv. Healthc. Mater. 2017, 6, 1700630.

100. Lu, Q.; Moore, J.M.; Huang, G.; Mount, A.S.; Rao, A.M.; Larcom, L.L.; Ke, P.C. RNA polymer translocation with single-walled carbon nanotubes. Nano Lett. 2004, 4, 2473-2477. [CrossRef]

101. Kim, T.H.; Kim, M.; Eltohamy, M.; Yun, Y.R.; Jang, J.H.; Kim, H.W. Efficacy of mesoporous silica nanoparticles in delivering BMP-2 plasmid DNA for in vitro osteogenic stimulation of mesenchymal stem cells. J. Biomed. Mater. Res. Part A 2013, 101, 1651-1660. [CrossRef] [PubMed]

102. Wu, T.; Tan, L.; Cheng, N.; Yan, Q.; Zhang, Y.F.; Liu, C.J.; Shi, B. PNIPAAM modified mesoporous hydroxyapatite for sustained osteogenic drug release and promoting cell attachment. Mater. Sci. Eng. C 2016, 62, 888-896. [CrossRef] [PubMed]

103. Al-Dosari, M.S.; Gao, X. Nonviral gene delivery: Principle, limitations, and recent progress. AAPS J. 2009, 11, 671-681. [CrossRef] [PubMed]

104. Samavedi, S.; Whittington, A.R.; Goldstein, A.S. Calcium phosphate ceramics in bone tissue engineering: A review of properties and their influence on cell behavior. Acta Biomater. 2013, 9, 8037-8045. [CrossRef]

105. Chai, Y.C.; Carlier, A.; Bolander, J.; Roberts, S.J.; Geris, L.; Schrooten, J.; Van Oosterwyck, H.; Luyten, F.P. Current views on calcium phosphate osteogenicity and the translation into effective bone regeneration strategies. Acta Biomater. 2012, 8, 3876-3887. [CrossRef]

106. Zayzafoon, M. Calcium/calmodulin signaling controls osteoblast growth and differentiation. J. Cell. Biochem. 2006, 97, 56-70. [CrossRef]

107. Barradas, A.M.C.; Fernandes, H.A.M.; Groen, N.; Chai, Y.C.; Schrooten, J.; Van de Peppel, J.; Van Leeuwen, J.P.T.M.; Van Blitterswijk, C.A.; De Boer, J. A calcium-induced signaling cascade leading to osteogenic differentiation of human bone marrow-derived mesenchymal stromal cells. Biomaterials 2012, 33, 3205-3215. [CrossRef]

108. Chen, X.; Bai, J.; Yuan, S.; Yu, C.; Huang, J.; Zhang, T.; Wang, K. Calcium phosphate nanoparticles are associated with inorganic phosphate-induced osteogenic differentiation of rat bone marrow stromal cells. Chem. Biol. Interact. 2015, 238, 111-117. [CrossRef]

109. Shih, Y.-R.V.; Hwang, Y.; Phadke, A.; Kang, H.; Hwang, N.S.; Caro, E.J.; Nguyen, S.; Siu, M.; Theodorakis, E.A.; Gianneschi, N.C.; et al. Calcium phosphate-bearing matrices induce osteogenic differentiation of stem cells through adenosine signaling. Proc. Natl. Acad. Sci. USA 2014, 111, 990-995. [CrossRef]

110. Rao, V.; Shih, Y.-R.V.; Kang, H.; Kabra, H.; Varghese, S. Adenosine Signaling Mediates Osteogenic Differentiation of Human Embryonic Stem Cells on Mineralized Matrices. Front. Bioeng. Biotechnol. 2015, 3, 1-10. [CrossRef]

111. Bakan, F. Gene Delivery by Hydroxyapatite and Calcium Phosphate Nanoparticles: A Review of Novel and Recent Applications. Available online: http://www.intechopen.com/books/hydroxyapatite-advancesin-composite-nanomaterials-biomedical-applications-and-its-technological-facets/gene-delivery-byhydroxyapatite-and-calcium-phosphate-nanoparticles-a-review-of-novel-and-recent-app (accessed on 4 October 2019). 
112. Chernousova, S.; Epple, M. Live-cell imaging to compare the transfection and gene silencing efficiency of calcium phosphate nanoparticles and a liposomal transfection agent. Gene Ther. 2017, 24, 282-289. [CrossRef] [PubMed]

113. Habibovic, P.; Bassett, D.C.; Doillon, C.J.; Gerard, C.; McKee, M.D.; Barralet, J.E. Collagen biomineralization in vivo by sustained release of inorganic phosphate ions. Adv. Mater. 2010, 22, 1858-1862. [CrossRef] [PubMed]

114. Qi, C.; Musetti, S.; Fu, L.H.; Zhu, Y.J.; Huang, L. Biomolecule-assisted green synthesis of nanostructured calcium phosphates and their biomedical applications. Chem. Soc. Rev. 2019, 48, 2698-2737. [CrossRef] [PubMed]

115. Gonzalez-Fernandez, T.; Sathy, B.N.; Hobbs, C.; Cunniffe, G.M.; McCarthy, H.O.; Dunne, N.J.; Nicolosi, V.; O’Brien, F.J.; Kelly, D.J. Mesenchymal stem cell fate following non-viral gene transfection strongly depends on the choice of delivery vector. Acta Biomater. 2017, 55, 226-238. [CrossRef] [PubMed]

116. Levingstone, T.J.; Herbaj, S.; Dunne, N.J. Calcium Phosphate Nanoparticles for Therapeutic Applications in Bone Regeneration. Nanomaterials 2019, 9, 1570. [CrossRef]

117. Graham, F.L.; Van der Eb, A.J. A new technique for the assay of infectivity of human adenovirus 5 DNA. Virology 1973, 52, 456-467. [CrossRef]

118. Ridi, F.; Meazzini, I.; Castroflorio, B.; Bonini, M.; Berti, D.; Baglioni, P. Functional calcium phosphate composites in nanomedicine. Adv. Colloid Interface Sci. 2017, 244, 281-295. [CrossRef]

119. Welzel, T.; Radtke, I.; Meyer-Zaika, W.; Heumann, R.; Epple, M. Transfection of cells with custom-made calcium phosphate nanoparticles coated with DNA. J. Mater. Chem. 2004, 14, 2213-2217. [CrossRef]

120. Dorozhkin, S.V. Calcium orthophosphate bioceramics. Ceram. Int. 2015, 41, 13913-13966. [CrossRef]

121. Neumann, S.; Kovtun, A.; Dietzel, I.D.; Epple, M.; Heumann, R. The use of size-defined DNA-functionalized calcium phosphate nanoparticles to minimise intracellular calcium disturbance during transfection. Biomaterials 2009, 30, 6794-6802. [CrossRef]

122. Lee, D.; Upadhye, K.; Kumta, P.N. Nano-sized calcium phosphate (CaP) carriers for non-viral gene deilvery. Mater. Sci. Eng. B Solid-State Mater. Adv. Technol. 2012, 177, 289-302. [CrossRef]

123. Sokolova, V.; Epple, M. Inorganic Nanoparticles as Carriers of Nucleic Acids into Cells. Angew. Chem. Int. Ed. 2008, 47, 1382-1395. [CrossRef] [PubMed]

124. Ruvinov, E.; Kryukov, O.; Forti, E.; Korin, E.; Goldstein, M.; Cohen, S. Calcium-siRNA nanocomplexes: What reversibility is all about. J. Control. Release 2015, 203, 150-160. [CrossRef] [PubMed]

125. Goldshtein, M.; Forti, E.; Ruvinov, E.; Cohen, S. Mechanisms of cellular uptake and endosomal escape of calcium-siRNA nanocomplexes. Int. J. Pharm. 2016, 515, 46-56. [CrossRef]

126. Shi, Z.; Huang, X.; Cai, Y.; Tang, R.; Yang, D. Size effect of hydroxyapatite nanoparticles on proliferation and apoptosis of osteoblast-like cells. Acta Biomater. 2009, 5, 338-345. [CrossRef]

127. Fontana, G.; Martin, H.L.; Lee, J.S.; Schill, K.; Hematti, P.; Murphy, W.L. Mineral-Coated Microparticles Enhance mRNA-Based Transfection of Human Bone Marrow Cells. Mol. Ther. Nucleic Acids 2019, 18, 455-464. [CrossRef]

128. Dorozhkin, S.V. Bioceramics of calcium orthophosphates. Biomaterials 2010, 31, 1465-1485. [CrossRef]

129. Chowdhury, E.H.; Kunou, M.; Nagaoka, M.; Kundu, A.K.; Hoshiba, T.; Akaike, T. High-efficiency gene delivery for expression in mammalian cells by nanoprecipitates of Ca-Mg phosphate. Gene 2004, 341, 77-82. [CrossRef]

130. Hanifi, A.; Fathi, M.H.; Mir Mohammad Sadeghi, H. Effect of strontium ions substitution on gene delivery related properties of calcium phosphate nanoparticles. J. Mater. Sci. Mater. Med. 2010, 21, 2601-2609. [CrossRef]

131. Hanifi, A.; Fathi, M.H.; Sadeghi, H.M.M.; Varshosaz, J. $\mathrm{Mg}^{2+}$ substituted calcium phosphate nano particles synthesis for non viral gene delivery application. J. Mater. Sci. Mater. Med. 2010, 21, 2393-2401. [CrossRef]

132. Adair, J.H.; Parette, M.P.; Altinoğlu, E.I.; Kester, M. Nanoparticulate alternatives for drug delivery. ACS Nano 2010, 4, 4967-4970. [CrossRef] [PubMed]

133. Olton, D.; Li, J.; Wilson, M.E.; Rogers, T.; Close, J.; Huang, L.; Kumta, P.N.; Sfeir, C. Nanostructured calcium phosphates (NanoCaPs) for non-viral gene delivery: Influence of the synthesis parameters on transfection efficiency. Biomaterials 2007, 28, 1267-1279. [CrossRef] [PubMed]

134. Lin, K.; Wu, C.; Chang, J. Advances in synthesis of calcium phosphate crystals with controlled size and shape. Acta Biomater. 2014, 10, 4071-4102. [CrossRef] [PubMed] 
135. Xu, J.L.; Khor, K.A.; Sui, J.J.; Zhang, J.H.; Chen, W.N. Protein expression profiles in osteoblasts in response to differentially shaped hydroxyapatite nanoparticles. Biomaterials 2009, 30, 5385-5391. [CrossRef]

136. Xu, Z.; Liu, C.; Wei, J.; Sun, J. Effects of four types of hydroxyapatite nanoparticles with different nanocrystal morphologies and sizes on apoptosis in rat osteoblasts. J. Appl. Toxicol. 2012, 32, 429-435. [CrossRef]

137. Roohani-Esfahani, S.I.; Zreiqat, H. Nanoparticles: A promising new therapeutic platform for bone regeneration? Nanomedicine 2017, 12, 419-422. [CrossRef]

138. Reardon, P.J.T.; Huang, J.; Tang, J. Mesoporous calcium phosphate bionanomaterials with controlled morphology by an energy-efficient microwave method. J. Biomed. Mater. Res. Part A 2015, 103, 3781-3789. [CrossRef]

139. Fröhlich, E. The role of surface charge in cellular uptake and cytotoxicity of medical nanoparticles. Int. J. Nanomedicine 2012, 7, 5577-5591. [CrossRef]

140. Chen, L.; Mccrate, J.M.; Lee, J.C.M.; Li, H. The role of surface charge on the uptake and biocompatibility of hydroxyapatite nanoparticles with osteoblast cells. Nanotechnology 2011, 22, 105708. [CrossRef]

141. Zhu, X.; Fan, H.; Li, D.; Xiao, Y.; Zhang, X. Protein Adsorption and Zeta Potentials of a Biphasic Calcium Phosphate Ceramic Under Various Conditions. J. Biomed. Mater. Res. Part B Appl. Biomater. 2007, 82B, 65-73. [CrossRef]

142. Zhang, M.; Kataoka, K. Nano-structured composites based on calcium phosphate for cellular delivery of therapeutic and diagnostic agents. Nano Today 2009, 4, 508-517. [CrossRef]

143. Bisht, S.; Bhakta, G.; Mitra, S.; Maitra, A. pDNA loaded calcium phosphate nanoparticles: Highly efficient non-viral vector for gene delivery. Int. J. Pharm. 2005, 288, 157-168. [CrossRef] [PubMed]

144. Sokolova, V.; Rotan, O.; Klesing, J.; Nalbant, P.; Buer, J.; Knuschke, T.; Westendorf, A.M.; Epple, M. Calcium phosphate nanoparticles as versatile carrier for small and large molecules across cell membranes. J. Nanopart. Res. 2012, 14, 910. [CrossRef]

145. Turon, P.; del Valle, L.; Alemán, C.; Puiggalí, J. Biodegradable and Biocompatible Systems Based on Hydroxyapatite Nanoparticles. Appl. Sci. 2017, 7, 60. [CrossRef]

146. Tenkumo, T.; Vanegas Sáenz, J.R.; Takada, Y.; Takahashi, M.; Rotan, O.; Sokolova, V.; Epple, M.; Sasaki, K. Gene transfection of human mesenchymal stem cells with a nano-hydroxyapatite-collagen scaffold containing DNA-functionalized calcium phosphate nanoparticles. Genes Cells 2016, 21, 682-695. [CrossRef]

147. Wagner, D.E.; Bhaduri, S.B. Progress and Outlook of Inorganic Nanoparticles for Delivery of Nucleic Acid Sequences Related to Orthopedic Pathologies: A Review. Tissue Eng. Part B Rev. 2012, 18, 1-14. [CrossRef]

148. Tobin, L.A.; Xie, Y.; Tsokos, M.; Chung, S.I.; Merz, A.A.; Arnold, M.; Li, G.; Malech, H.L.; Kwong, K.F. Pegylated siRNA-loaded calcium phosphate nanoparticle-driven amplification of cancer cell internalization in vivo. Biomaterials 2013, 34, 2980-2990. [CrossRef]

149. Neuhaus, B.; Frede, A.; Westendorf, A.M.; Epple, M. Gene silencing of the pro-inflammatory cytokine TNF-a with siRNA delivered by calcium phosphate nanoparticles, quantified by different methods. J. Mater. Chem. B 2015, 7186, 7186-7193. [CrossRef]

150. Lee, M.S.; Lee, J.E.; Byun, E.; Kim, N.W.; Lee, K.; Lee, H.; Sim, S.J.; Lee, D.S.; Jeong, J.H. Target-specific delivery of siRNA by stabilized calcium phosphate nanoparticles using dopa-hyaluronic acid conjugate. J. Control. Release 2014, 192, 122-130. [CrossRef]

151. Li, J.; Chen, Y.-C.; Tseng, Y.-C.; Mozumdar, S.; Huang, L. Biodegradable calcium phosphate nanoparticle with lipid coating for systemic siRNA delivery. J. Control. Release 2010, 142, 416-421. [CrossRef]

152. Kauffman, W.B.; Fuselier, T.; He, J.; Wimley, W.C. Mechanism Matters: A Taxonomy of Cell Penetrating Peptides. Trends Biochem Sci. 2016, 40, 749-764. [CrossRef] [PubMed]

153. Sharma, S.; Verma, A.; Teja, B.V.; Pandey, G.; Mittapelly, N.; Trivedi, R.; Mishra, P.R. An insight into functionalized calcium based inorganic nanomaterials in biomedicine: Trends and transitions. Colloids Surf. B Biointerfaces 2015, 133, 120-139. [CrossRef] [PubMed]

154. Pack, D.W.; Hoffman, A.S.; Pun, S.; Stayton, P.S. Design and development of polymers for gene delivery. Nat. Rev. Drug Discov. 2005, 4, 581-593. [CrossRef] [PubMed]

155. Giger, E.V.; Castagner, B.; Räikkönen, J.; Mönkkönen, J.; Leroux, J.C. siRNA Transfection with Calcium Phosphate Nanoparticles Stabilized with PEGylated Chelators. Adv. Healthc. Mater. 2013, 2, 134-144. [CrossRef] [PubMed]

156. Lee, K.; Oh, M.H.; Lee, M.S.; Nam, Y.S.; Park, T.G.; Jeong, J.H. Stabilized calcium phosphate nano-aggregates using a dopa-chitosan conjugate for gene delivery. Int. J. Pharm. 2013, 445, 196-202. [CrossRef] [PubMed] 
157. Schmidt, H.T.; Gray, B.L.; Wingert, P.A.; Ostafin, A.E. Assembly of aqueous-cored calcium phosphate nanoparticles for drug delivery. Chem. Mater. 2004, 16, 4942-4947. [CrossRef]

158. Pittella, F.; Zhang, M.; Lee, Y.; Kim, H.J.; Tockary, T.; Osada, K.; Ishii, T.; Miyata, K.; Nishiyama, N.; Kataoka, K. Enhanced endosomal escape of siRNA-incorporating hybrid nanoparticles from calcium phosphate and PEG-block charge-conversional polymer for efficient gene knockdown with negligible cytotoxicity. Biomaterials 2011, 32, 3106-3114. [CrossRef]

159. Kakizawa, Y.; Furukawa, S.; Kataoka, K. Block copolymer-coated calcium phosphate nanoparticles sensing intracellular environment for oligodeoxynucleotide and siRNA delivery. J. Control. Release 2004, 97, 345-356. [CrossRef]

160. Zhang, M.; Lshii, A.; Nishiyama, N.; Matsumoto, S.; Lshii, T.; Yamasaki, Y.; Kataoka, K. PEGylated calcium phosphate nanocomposites as smart environment-sensitive carriers for siRNA delivery. Adv. Mater. 2009, 21, 3520-3525. [CrossRef]

161. Devarasu, T.; Saad, R.; Ouadi, A.; Frisch, B.; Robinet, E.; Laquerrière, P.; Voegel, J.-C.; Baumert, T.; Ogier, J.; Meyer, F. Potent calcium phosphate nanoparticle surface coating for in vitro and in vivo siRNA delivery: A step toward multifunctional nanovectors. J. Mater. Chem. B 2013, 1, 4692. [CrossRef]

162. Choi, B.; Cui, Z.-K.; Kim, S.; Fan, J.; Wu, B.M.; Lee, M. Glutamine-chitosan modified calcium phosphate nanoparticles for efficient siRNA delivery and osteogenic differentiation. J. Mater. Chem. B. Mater. Biol. Med. 2015, 3, 6448-6455. [CrossRef] [PubMed]

163. Lee, J.E.; Yin, Y.; Lim, S.Y.; Kim, E.S.; Jung, J.; Kim, D.; Park, J.W.; Lee, M.S.; Jeong, J.H. Enhanced Transfection of Human Mesenchymal Stem Cells Using a Hyaluronic Acid/Calcium Phosphate Hybrid Gene Delivery System. Polymers 2019, 11, 798. [CrossRef] [PubMed]

164. Yang, Y.; Li, J.; Liu, F.; Huang, L. Systemic delivery of siRNA via LCP nanoparticle efficiently inhibits lung metastasis. Mol. Ther. 2012, 20, 609-615. [CrossRef] [PubMed]

165. Sathy, B.N.; Olvera, D.; Gonzalez-Fernandez, T.; Cunniffe, G.M.; Pentlavalli, S.; Chambers, P.; Jeon, O.; Alsberg, E.; McCarthy, H.O.; Dunne, N.; et al. RALA complexed $\alpha$-TCP nanoparticle delivery to mesenchymal stem cells induces bone formation in tissue engineered constructs in vitro and in vivo. J. Mater. Chem. B 2017, 5, 1753-1764. [CrossRef]

166. Park, T.G.; Jeong, J.H.; Kim, S.W. Current status of polymeric gene delivery systems. Adv. Drug Deliv. Rev. 2006, 58, 467-486. [CrossRef]

167. Ossipov, D.A. Bisphosphonate-modified biomaterials for drug delivery and bone tissue engineering. Expert Opin. Drug Deliv. 2015, 12, 1443-1458. [CrossRef]

168. Giger, E.V.; Puigmartí-Luis, J.; Schlatter, R.; Castagner, B.; Dittrich, P.S.; Leroux, J.C. Gene delivery with bisphosphonate-stabilized calcium phosphate nanoparticles. J. Control. Release 2011, 150, 87-93. [CrossRef]

169. Pittella, F.; Cabral, H.; Maeda, Y.; Mi, P.; Watanabe, S.; Takemoto, H.; Kim, H.J.; Nishiyama, N.; Miyata, K.; Kataoka, K. Systemic siRNA delivery to a spontaneous pancreatic tumor model in transgenic mice by PEGylated calcium phosphate hybrid micelles. J. Control. Release 2014, 178, 18-24. [CrossRef]

170. Lee, Y.; Fukushima, S.; Bae, Y.; Hiki, S.; Ishii, T.; Kataoka, K. A protein nanocarrier from charge-conversion polymer in response to endosomal pH. J. Am. Chem. Soc. 2007, 129, 5362-5363. [CrossRef]

171. Kakizawa, Y.; Miyata, K.; Furukawa, S.; Kataoka, K. Size-Controlled Formation of a Calcium Phosphate-Based Organic-Inorganic Hybrid Vector for Gene Delivery Using Poly(ethylene glycol)-block-poly(aspartic acid). Adv. Mater. 2004, 16, 699-702. [CrossRef]

172. Kakizawa, Y.; Furukawa, S.; Ishii, A.; Kataoka, K. Organic-inorganic hybrid-nanocarrier of siRNA constructing through the self-assembly of calcium phosphate and PEG-based block aniomer. J. Control. Release 2006, 111, 368-370. [CrossRef] [PubMed]

173. Hatakeyama, H.; Akita, H.; Harashima, H. A multifunctional envelope type nano device (MEND) for gene delivery to tumours based on the EPR effect: A strategy for overcoming the PEG dilemma. Adv. Drug Deliv. Rev. 2011, 63, 152-160. [CrossRef] [PubMed]

174. Petersen, H.; Fechner, P.M.; Martin, A.L.; Kunath, K.; Stolnik, S.; Roberts, C.J.; Fischer, D.; Davies, M.C.; Kissel, T. Polyethylenimine-graft-poly(ethylene glycol) copolymers: Influence of copolymer block structure on DNA complexation and biological activities as gene delivery system. Bioconjug. Chem. 2002, 13, 845-854. [CrossRef] [PubMed] 
175. Tang, J.; Chen, J.Y.; Liu, J.; Luo, M.; Wang, Y.J.; Wei, X.W.; Gao, X.; Wang, B.L.; Liu, Y.B.; Yi, T.; et al. Calcium phosphate embedded PLGA nanoparticles: A promising gene delivery vector with high gene loading and transfection efficiency. Int. J. Pharm. 2012, 431, 210-221. [CrossRef]

176. Wang, K.-W.; Zhou, L.-Z.; Sun, Y.; Wu, G.-J.; Gu, H.-C.; Duan, Y.-R.; Chen, F.; Zhu, Y.-J. Calcium phosphate/PLGA-mPEG hybrid porous nanospheres: A promising vector with ultrahigh gene loading and transfection efficiency. J. Mater. Chem. 2010, 20, 1161-1166. [CrossRef]

177. Zhang, X.; Kovtun, A.; Mendoza-Palomares, C.; Oulad-Abdelghani, M.; Fioretti, F.; Rinckenbach, S.; Mainard, D.; Epple, M.; Benkirane-Jessel, N. SiRNA-loaded multi-shell nanoparticles incorporated into a multilayered film as a reservoir for gene silencing. Biomaterials 2010, 31, 6013-6018. [CrossRef]

178. Zeng, J.; Xiong, S.; Ding, L.; Zhou, J.; Li, J.; Qiu, P.; Liao, X.; Xiong, L.; Long, Z.; Liu, S. Study of bone repair mediated by recombination BMP-2/ recombination CXC chemokine Ligand-13-loaded hollow hydroxyapatite microspheres/chitosan composite. Life Sci. 2019, 234, 116743. [CrossRef]

179. Kozlova, D.; Chernousova, S.; Knuschke, T.; Buer, J.; Westendorf, A.M.; Epple, M. Cell targeting by antibody-functionalized calcium phosphatenanoparticles. J. Mater. Chem. 2012, 22, 396-404. [CrossRef]

180. Shim, G.; Kim, M.G.; Park, J.Y.; Oh, Y.K. Application of cationic liposomes for delivery of nucleic acids. Asian J. Pharm. Sci. 2013, 8, 120-128. [CrossRef]

181. Felgner, P.L.; Gadek, T.R.; Holm, M.; Roman, R.; Chan, H.W.; Wenz, M.; Northrop, J.P.; Ringold, G.M.; Danielsen, M. Lipofection: A highly efficient, lipid-mediated DNA-transfection procedure. Proc. Natl. Acad. Sci. USA 1987, 84, 7413-7417. [CrossRef]

182. Zhi, D.; Bai, Y.; Yang, J.; Cui, S.; Zhao, Y.; Chen, H.; Zhang, S. A review on cationic lipids with different linkers for gene delivery. Adv. Colloid Interface Sci. 2018, 253, 117-140. [CrossRef] [PubMed]

183. Zhou, C.; Yu, B.; Yang, X.; Huo, T.; Lee, L.J.; Barth, R.F.; Lee, R.J. Lipid-coated nano-calcium-phosphate (LNCP) for gene delivery. Int. J. Pharm. 2010, 392, 201-208. [CrossRef] [PubMed]

184. Richard, J.P.; Melikov, K.; Brooks, H.; Prevot, P.; Lebleu, B.; Chernomordik, L.V. Cellular uptake of unconjugated TAT peptide involves clathrin-dependent endocytosis and heparan sulfate receptors. J. Biol. Chem. 2005, 280, 15300-15306. [CrossRef] [PubMed]

185. Mayor, S.; Pagano, R.E. Pathways of clathrin-independent endocytosis. Nat. Rev. Mol. Cell Biol. 2007, 8, 603-612. [CrossRef] [PubMed]

186. Vandenbroucke, R.E.; De Smedt, S.C.; Demeester, J.; Sanders, N.N. Cellular entry pathway and gene transfer capacity of TAT-modified lipoplexes. Biochim. Biophys. Acta Biomembr. 2007, 1768, 571-579. [CrossRef]

187. Futaki, S.; Nakase, I.; Tadokoro, A.; Takeuchi, T.; Jones, A.T. Arginine-rich peptides and their internalization mechanisms. Biochem. Soc. Trans. 2007, 35, 784-787. [CrossRef] [PubMed]

188. Wang, F.; Wang, Y.; Zhang, X.; Zhang, W.; Guo, S.; Jin, F. Recent progress of cell-penetrating peptides as new carriers for intracellular cargo delivery. J. Control. Release 2014, 174, 126-136. [CrossRef] [PubMed]

189. Guo, Z.; Peng, H.; Kang, J.; Sun, D. Cell-penetrating peptides: Possible transduction mechanisms and therapeutic applications (Review). Biomed. Rep. 2016, 4, 528-534. [CrossRef]

190. Farkhani, S.M.; Valizadeh, A.; Karami, H.; Mohammadi, S.; Sohrabi, N.; Badrzadeh, F. Cell penetrating peptides: Efficient vectors for delivery of nanoparticles, nanocarriers, therapeutic and diagnostic molecules. Peptides 2014, 57, 78-94. [CrossRef]

191. Deshayes, S.; Heitz, A.; Morris, M.C.; Charnet, P.; Divita, G.; Heitz, F. Insight into the Mechanism of Internalization of the Cell-Penetrating Carrier Peptide Pep-1 through Conformational Analysis. Biochemistry 2004, 43, 1449-1457. [CrossRef]

192. Akdag, I.O.; Ozkirimli, E. The uptake mechanism of the cell-penetrating pVEC peptide. J. Chem. 2013, 2013. [CrossRef]

193. Morris, M.C.; Depollier, J.; Mery, J.; Heitz, F.; Divita, G. A peptide carrier for the delivery of biologically active proteins into mammalian cells. Nat. Biotechnol. 2001, 19, 1173-1176. [CrossRef] [PubMed]

194. Assa-Munt, N.; Jia, X.; Laakkonen, P.; Ruoslahti, E. Solution structures and integrin binding activities of an RGD peptide with two isomers. Biochemistry 2001, 40, 2373-2378. [CrossRef] [PubMed]

195. Mccarthy, H.O.; McCaffrey, J.; Mccrudden, C.M.; Zholobenko, A.; Ali, A.A.; McBride, J.W.; Massey, A.S.; Pentlavalli, S.; Chen, K.H.; Cole, G.; et al. Development and characterization of self-assembling nanoparticles using a bio-inspired amphipathic peptide for gene delivery. J. Control. Release 2014, 189, 141-149. [CrossRef] [PubMed] 
196. Bennett, R.; Yakkundi, A.; McKeen, H.D.; McClements, L.; McKeogh, T.J.; McCrudden, C.M.; Arthur, K.; Robson, T.; McCarthy, H.O. RALA-mediated delivery of FKBPL nucleic acid therapeutics. Nanomedicine (Lond). 2015, 10, 2989-3001. [CrossRef]

197. Bolhassani, A. Potential efficacy of cell-penetrating peptides for nucleic acid and drug delivery in cancer. Biochim. Biophys. Acta Rev. Cancer 2011, 1816, 232-246. [CrossRef]

198. Suh, J.S.; Lee, J.Y.; Choi, Y.J.; You, H.K.; Hong, S.D.; Chung, C.P.; Park, Y.J. Intracellular delivery of cell-penetrating peptide-transcriptional factor fusion protein and its role in selective osteogenesis. Int. J. Nanomed. 2014, 9, 1153-1166.

(c) (1)

(C) 2020 by the authors. Licensee MDPI, Basel, Switzerland. This article is an open access article distributed under the terms and conditions of the Creative Commons Attribution (CC BY) license (http://creativecommons.org/licenses/by/4.0/). 